\title{
Quantitative modeling of the physiology of ascites in portal hypertension
}

\author{
David G Levitt ${ }^{1 *}$ and Michael D Levitt ${ }^{2}$
}

\begin{abstract}
Although the factors involved in cirrhotic ascites have been studied for a century, a number of observations are not understood, including the action of diuretics in the treatment of ascites and the ability of the plasma-ascitic albumin gradient to diagnose portal hypertension. This communication presents an explanation of ascites based solely on pathophysiological alterations within the peritoneal cavity. A quantitative model is described based on experimental vascular and intraperitoneal pressures, lymph flow, and peritoneal space compliance. The model's predictions accurately mimic clinical observations in ascites, including the magnitude and time course of changes observed following paracentesis or diuretic therapy.
\end{abstract}

Keywords: Ascites, Cirrhosis, Portal hypertension, Wedge pressure

\section{Background}

Ascites commonly is regarded as a clinical condition that can be understood in terms of classic physiological principals. The fundamental factors involved in the formation of ascites were established over a century ago when Starling [1] used observations of thoracic duct lymph flow and fluid absorption from the peritoneal space to support his classic description of the forces that determine capillary fluid balance.

Over the past 30 years, ascites research largely has focused on associated systemic abnormalities such as increases in cardiac output, blood volume, renal sodium retention and reduction in total systemic vascular resistance. Whether these systemic abnormalities are the effect or cause of ascites has been controversial. Rocco and Ware [2] review the two older competing hypotheses: 1) the "underfill" theory in which ascites formation is the primary event causing the systemic changes, versus 2) the "overflow" theory in which renal sodium retention is the primary event. Recent reports [3-9], which have emphasized the renal and systemic effects of vasoactive compounds such as nitric oxide and the "hyperdynamic syndrome", favor the "forward" theory,

\footnotetext{
* Correspondence: levit001@umn.edu

'Department of Integrative Biology and Physiology, University of Minnesota, 6-125 Jackson Hall, 321 Church St. S. E., Minneapolis, MN 55455, USA Full list of author information is available at the end of the article
}

which represents a synthesis of the underfill and overflow theories.

This focus on renal and systemic effects has led investigators to lose sight of the local factors within the peritoneal cavity that actually are responsible for the accumulations of ascites. For example, a recent review [10] of ascites summarized the pathogenesis as follows:

"The most acceptable theory for ascites formation is peripheral arterial vasodilation leading to underfilling of circulatory volume. This triggers the baroreceptormediated activation of renin-angiotensin-aldosterone system, sympathetic nervous system and nonosmotic release of vasopressin to restore circulatory integrity. The result is an avid sodium and water retention, identified as a preascitic state. This condition will evolve in overt fluid retention and ascites, as the liver disease progresses. Once ascites is present, most therapeutic modalities are directed on maintaining negative sodium balance, including salt restriction, bed rest and diuretics."

How the above described systemic changes translate into ascites accumulation is poorly understood at the quantitative level, and, in fact, is seldom discussed (as illustrated by the above quote). As a result, several clinically important observations remain unexplained. For example, how do the systemic alterations induced by salt restriction and diuretics lead to a reduction in ascites [11] and why does the commonly employed measurement of plasma-ascitic fluid albumin gradient
C Biomed Central

(c) 2012 Levitt and Levitt; licensee BioMed Central Ltd. This is an Open Access article distributed under the terms of the Creative Commons Attribution License (http://creativecommons.org/licenses/by/2.0), which permits unrestricted use, distribution, and reproduction in any medium, provided the original work is properly cited. 
accurately diagnose portal hypertension. In an attempt to better understand the physiology of ascites, we present what appears to be the first quantitative model of the formation and removal of ascitic fluid. In this model, ascites accumulation is explained solely by pathophysiological alterations within the peritoneal cavity; systemic abnormalities are considered relevant only to the extent that they alter intraperitoneal physiology. Insights derived from this model may provide answers to previously unexplained clinical observations in patients with ascites.

Section I of the Discussion provides a brief quantitative description of the factors involved in fluid balance in the peritoneal space of normal subjects. Section II presents an analysis of the pathological abnormalities in the peritoneal cavity that are involved in the accumulation of ascites. This discussion includes mechanistic explanations for several clinically important, but poorly understood phenomena. Finally, in Section III, using a reasonable set of assumptions, a quantitative physical model describing ascites accumulation is developed and discussed. This model accurately predicts the magnitude and time course of the changes in ascites volume that are observed clinically with diuretic treatment or paracentesis. In sections I-III we have focused on the key factors and main supporting experimental results. The attached Additional file 1 (Section A), provides a more detailed discussion of the evidence supporting (or contradicting) the model's assumptions.

\section{Discussion}

I. Physiological model of normal peritoneal fluid balance A schematic diagram of the peritoneal space is shown in Figure 1. Two compartments exchange with this space, the liver and the "intestine". The "intestine" is assumed to represent all non-hepatic, intraperitoneal organs (including the mesentery). The liver has a dual blood flow-the portal vein and the hepatic artery. One branch of the hepatic artery (about $2 / 3$ of flow) directly connects to the sinusoids and the other branch supplies the peribiliary capillaries of the bile ducts which then drain into the sinusoids [12]. The intestinal capillary and liver sinusoidal colloid osmotic pressures are assumed to equal the systemic plasma colloid osmotic pressure $\left(\Pi_{\mathrm{P}}\right)$.

\section{A. Fluid transport across the intestinal capillaries}

Fluid balance across the intestinal capillaries is a function of the hydrostatic and colloid osmotic pressures. Since the intestinal capillary membrane is relatively impermeable to protein, the volume flux between the capillary and tissue space $\left(J_{C}\right)$ is described by Starling's relation:

$$
J_{C}=L_{C}\left[\left(P_{C}-P_{I}\right)-\left(\Pi_{P}-\Pi_{I}\right)\right]
$$

where $\mathrm{J}_{\mathrm{C}}$ is the flux across the capillary, $\mathrm{L}_{\mathrm{C}}$ is the capillary hydraulic permeability, and $\mathrm{P}_{C}$ and $\mathrm{P}_{\mathrm{I}}$ are the hydraulic pressures in the capillary and tissue and $\Pi_{P}$ and $\Pi_{I}$ are the oncotic pressures in the capillary and tissue. The capillary membrane has a slow diffusional leak of protein (primarily albumin). In the normal steady state, this slow leak is balanced by protein removal from the tissue space by the "intestinal" lymph flow, and the interstitial protein concentration is roughly $70 \%$ of the plasma concentration [13]. Because the hydraulic permeability is large compared to this slow leak, to a first approximation $\mathrm{J}_{\mathrm{C}} \approx 0$ and the difference in hydraulic pressure across the capillary equals the oncotic pressure difference:

$$
\Pi_{P}-\Pi_{I}=P_{C}-P_{I}
$$

As discussed in the next section, $\mathrm{P}_{\mathrm{I}}$ is approximately equal to $\mathrm{P}_{\mathrm{A}}$ (intra-abdominal pressure) so that:

$$
\Pi_{I} \approx \Pi_{P}+P_{A}-P_{C}
$$

Normally, the plasma colloid osmotic pressure $\left(\Pi_{\mathrm{P}}\right)$ is about $25 \mathrm{~mm} \mathrm{Hg}$ and the supine intra-abdominal pressure $\left(P_{A}\right)$ is about $2 \mathrm{~mm} \mathrm{Hg}$ [14]. Although direct experimental measurement of the intestinal hydrostatic capillary $\left(\mathrm{P}_{\mathrm{C}}\right)$ and tissue colloid osmotic $\left(\Pi_{\mathrm{I}}\right)$ pressures are difficult and uncertain (see Additional file 1 Section IA for more details), an estimate of the normal values [15] are $P_{C}=9$ and $\Pi_{I}=18 \mathrm{~mm} \mathrm{Hg}$, which are consistent with eq. (3). This is a dynamic equilibrium. If, for example, capillary pressure $\left(\mathrm{P}_{\mathrm{C}}\right)$ is raised (e.g., by constricting the portal vein), there will be an initial increase in capillary filtration $\left(\mathrm{J}_{C}\right.$, eq. (1)) increasing intestinal lymph flow and "washing down" the tissue protein $\left(\Pi_{\mathrm{I}}\right)$ until a new steady state relation (eq. (3)) is established.

\section{B. Fluid transport across the intestinal mesothelium}

The mesothelial membrane (Figure 1) separates the intestinal tissue space from the peritoneal space. It is assumed that the "intestinal" mesothelial and capillary membrane have similar protein permeability properties, with the rate of fluid exchange between the tissue and peritoneal space $\left(\mathrm{J}_{\mathrm{I}}\right)$ described by:

$$
J_{I}=L_{I}\left[\left(P_{I}-P_{A}\right)-\left(\Pi_{I}-\Pi_{A}\right)\right]
$$

where $P_{A}$ and $\Pi_{A}$ are the hydrostatic and colloid osmotic pressures in the peritoneal (ascitic) space and $\mathrm{L}_{\mathrm{I}}$ is the mesothelial hydraulic permeability. It is also assumed that the mesothelial membrane cannot support appreciable mechanical forces so that, to a first approximation, there is no hydrostatic pressure gradient across this membrane:

$$
P_{I}=P_{A}
$$

and eq. (4) reduces to:

$$
J_{I}=L_{I}\left[\Pi_{A}-\Pi_{I}\right]
$$




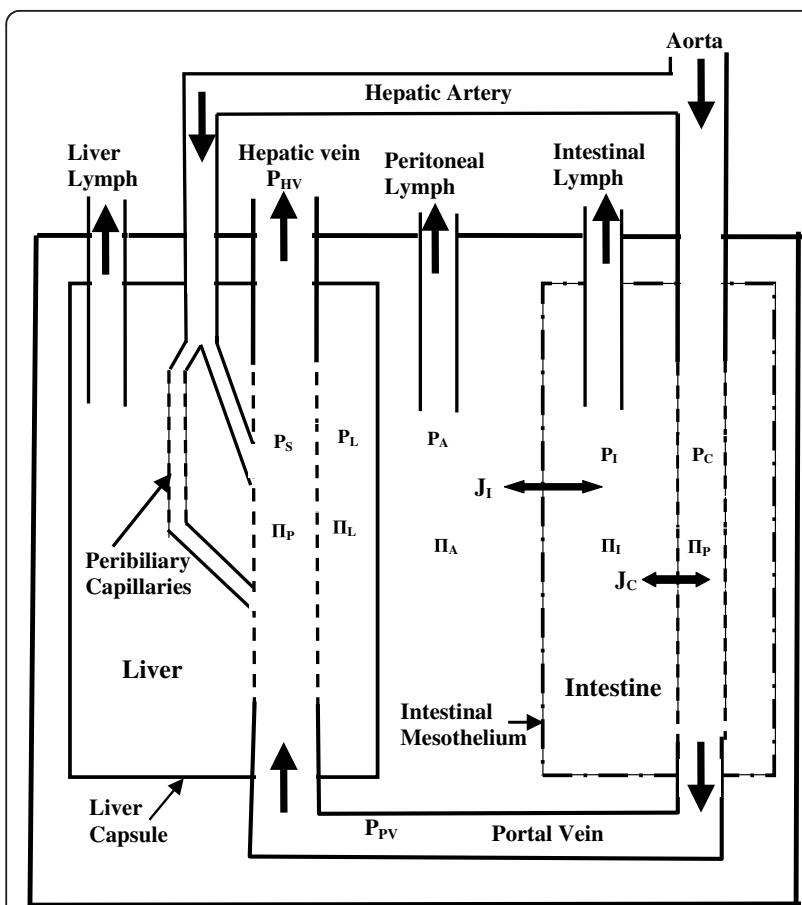

Figure 1 Schematic diagram of the peritoneal space. The "intestine" represents all non-hepatic, intraperitoneal organs (including the mesentery). The symbols $P$ and $\Pi$ indicate the hydrostatic and colloid osmotic pressure of the different compartments. See "Notation" for a definition of all the terms.

As discussed in detail in the Additional file 1 Section IB, the mesothelial barrier is ignored in the peritoneal dialysis literatures where it is assumed that this membrane is highly permeable to both protein and fluid. This assumption would not significantly change any of our model results or conclusions and, as is shown Section III, the quantitative steady state relations are identical, with or without, a mesothelial barrier. We feel experimental evidence supporting a significant mesothelial barrier is sufficient to keep this barrier in the model.

\section{Fluid transport across the liver}

The fenestrated liver sinusoids allow relatively free passage of proteins between the blood and tissue [16]. Thus, to a first approximation, the sinusoidal and tissue hydrostatic [17] and colloid osmotic pressures [18] are approximately equal:

$$
P_{L} \approx P_{S} \quad \Pi_{L} \approx \Pi_{P}
$$

The normal liver sinusoidal pressure $\left(\mathrm{P}_{\mathrm{S}}\right)$ and, therefore, the liver tissue pressure $\left(\mathrm{P}_{\mathrm{L}}\right)$ is about $5 \mathrm{~mm} \mathrm{Hg}$ (see Section IIC), significantly greater than the normal pressure in the peritoneal space $\left(\mathrm{P}_{\mathrm{A}} \approx 2 \mathrm{mmHg}\right)$. It follows that the liver capsule, in contrast to the intestinal mesothelium, is able to maintain a hydrostatic pressure difference between the tissue and peritoneal space.
Assuming that the capsule is relatively impermeable to albumin, the pressure difference between the liver tissue and peritoneal space $\left(\mathrm{P}_{\mathrm{L}}-\mathrm{P}_{\mathrm{A}}\right)$ would have to overcome the tissue colloid osmotic pressure $(\approx 25 \mathrm{mmHg})$ before there would be net fluid movement across the liver surface. As is discussed below, fluid leaks from the liver into the peritoneal space at pressures well below $25 \mathrm{~mm}$ $\mathrm{Hg}$ indicating that the source of this fluid is rupture of either the capsule or surface lymphatics.

\section{$D$. Fluid exchange in the peritoneal space}

Normal fluid movement between the peritoneal space and the systemic circulation is a combination of the "intestinal" mesothelium $\left(\mathrm{J}_{\mathrm{I}}\right)$ flux and the peritoneal lymph drainage (as discussed above, liver fluid flux is normally low). Since the mesothelial hydraulic permeability $\left(\mathrm{L}_{\mathrm{I}}\right)$ should be relatively large compared to the normal small lymph flow, to a first approximation $\mathrm{J}_{\mathrm{I}}=0$ and, from eq. (6), the peritoneal $\left(\Pi_{\mathrm{A}}\right)$ and the "intestinal" $\left(\Pi_{\mathrm{I}}\right)$ colloid osmotic pressures are equal:

$$
\Pi_{\mathrm{A}} \approx \Pi_{I}
$$

The peritoneal lymph drainage (Figure 1) removes fluid in bulk, with no sieving of the peritoneal protein concentration $[19,20]$. Our limited understanding of the rate of peritoneal lymph flow and its dependence on intra-abdominal pressure and volume is discussed in more detail in Section IID.

\section{Factors involved in the formation of Ascites in portal hypertension}

\section{A. Increase in portal vein pressure}

In the absence of increased hepatic sinusoidal pressure, marked elevations in portal vein pressure are required to induce ascites. Moderate increases in portal pressure induced experimentally via portal vein constriction [21] or clinically by portal vein thrombosis [22] do not result in appreciable ascites. This observation is explained by the above model. The peritoneal cavity normally contains a small amount of fluid (up to $100 \mathrm{ml}$ ) that is in osmotic equilibrium with intestinal tissue (eq. (8)). A rise in portal pressure elevates intestinal capillary pressure, increasing capillary filtration $\left(\mathrm{J}_{\mathrm{C}}\right.$, eq. (1)) and intestinal lymph flow. This washes out tissue protein, and the tissue colloid osmotic pressure $\left(\Pi_{\mathrm{I}}\right)$ falls until a new steady state (eq. (2)) is established. This decrease in $\Pi_{I}$ produces an osmotic water flux from intestinal tissue into the peritoneal space (eq. (6)), diluting the peritoneal protein until a new steady state is reached in which peritoneal colloid osmotic pressure equals the low value in the intestinal tissue (eq. (8)). This initial increase in peritoneal (ascitic) volume is small. For example, a reduction of tissue protein by a factor of two would result in a doubling of the initial small peritoneal 
volume. The lymphatic drainage of the peritoneal cavity brings the peritoneal volume back towards its original volume. The important point is that a new equilibrium will be rapidly established in which the volume flux between the intestine and peritoneal space is zero at the increased portal and intestinal capillary pressure, and the elevation in portal pressure does not produce appreciable ascites. This dynamic equilibrium reaches its limit when the intestinal tissue albumin $\left(\Pi_{\mathrm{I}}\right.$, eq. (3)), is washed down to 0 , corresponding to a maximum limiting capillary pressure $\left(\mathrm{P}_{\mathrm{C}}{ }^{\max }\right)$ described by:

$$
P_{C}^{\max }=\Pi_{P}+P_{A}
$$

At the normal $\mathrm{P}_{\mathrm{A}}$ of $2 \mathrm{mmHg}$, this limiting capillary pressure is about $27 \mathrm{~mm} \mathrm{Hg}$. Since the intestinal capillary pressure is about $3 \mathrm{~mm} \mathrm{Hg}$ greater than portal vein $\left(\mathrm{P}_{\mathrm{PV}}\right)$ pressure $[15,23]$, this limit corresponds to a $\mathrm{P}_{\mathrm{PV}}$ of about $24 \mathrm{~mm} \mathrm{Hg}$. This is consistent with the experimental results of Witte et. al. [24] that the intestine did not leak large volumes of ascetic fluid until the portal pressure reached about $26 \mathrm{~mm} \mathrm{Hg}\left(\mathrm{P}_{\mathrm{A}}=2 \mathrm{mmHg}\right)$. Since $\mathrm{P}_{\mathrm{C}}{ }^{\max }$ depends on $\mathrm{P}_{\mathrm{A}}$ (eq. (9)), a patient with severe ascites and a $\mathrm{P}_{\mathrm{A}}$ of $15 \mathrm{~mm} \mathrm{Hg}$ would not exceed this maximum until $\mathrm{P}_{\mathrm{PV}}$ was greater than $37 \mathrm{~mm} \mathrm{Hg}$, a value seldom observed clinically. (See Additional file 1, Section IE for more details).

\section{$B$. Increase in liver sinusoidal pressure}

Ascites readily forms when liver sinusoidal pressure is increased secondary to cirrhosis or obstruction of the hepatic veins or the inferior vena cava. This can be explained in terms of the model shown in Figure 1. As discussed above, the sinusoids are highly permeable to albumin and the liver tissue hydrostatic and colloid osmotic pressures are approximately equal to that of the sinusoids (eq. (7)), producing a hydrostatic pressure difference of $\left(\mathrm{P}_{\mathrm{L}}-\mathrm{P}_{\mathrm{A}}\right)$ across the liver capsule. Increase in the sinusoidal pressure results in a flux of fluid into the interstitial space which elevates tissue pressure and hepatic lymph flow $[17,18]$. The crucial event in ascites is the rupturing of either the liver capsule and/or the surface lymphatics allowing high protein tissue fluid $\left(\Pi_{\mathrm{L}}\right.$ $\approx \Pi_{\mathrm{p}}$, eq. (7)) to leak into the peritoneal space.

This protein leak from the liver surface is supported by a number of direct observations. Experimental inferior vena cava constriction leads to obvious "weeping" of fluid droplets from the liver surface [25-27] while the other visceral surfaces appear dry [27]. Clinical evidence that the weeping liver is the source of ascites protein is provided by the observation of Dumont and Mulholland [28] that "Lymph leaking from clusters of bulging lymphatics on the liver capsule and at the porta hepatis often is encountered at laparotomy in patients with Laennec's cirrhosis". Kuntz and Kuntz [29] provide a dramatic image of "Numerous, partially ruptured lymphocysts ... on the liver surface with extravasation of protein-rich lymph in alcoholic cirrhosis" (Figure 16.5, p. 298). Tameda et. al. [30] observed "small lymphatic vesicles" on the liver surface in 65 out 372 cirrhotic subjects during peritoneoscopy. During laparoscopy, Heit et. al. [31] reported that 4 of 10 cirrhotic livers had surface "...lymphatic blebs indicating dilated lymphatic channels ... and all 4 of these cases were complicated by ascites." Blebs were not seen in the absences of ascites. (see Additional file 1, Section ID for more details).

The protein concentration in ascitic peritoneal fluid in portal hypertension is low, roughly equal to the protein concentration of intestinal lymph [13]. There is a definite "capillarization" of liver sinusoids in cirrhosis $[32,33]$ and some authors $[34,35]$ have suggested that the ascites protein is roughly equal to the low liver tissue protein produced by this capillarization. However, even in severe cirrhosis sinusoidal fenestra are still present [33] and the liver lymph protein/plasma ratio (which is a measure of tissue protein) is about 0.6, much greater than the corresponding ascites protein ratio of 0.17 [13]. Furthermore, this liver lymph protein/ plasma ratio of 0.6 may underestimate the liver tissue protein because of lymphatic contributions from peribiliary capillaries and admixture from intestinal lymph [33]. An alternative explanation for this low ascites protein, which is directly supported by our quantitative model (Section III), is that the high protein fluid leaking from the liver pulls fluid osmotically from the "intestinal" tissue space (eq. (4)), diluting the peritoneal fluid protein until it roughly equals the intestinal tissue protein concentration. This implies that the rate of formation of ascitic fluid is determined primarily by two factors: the rate of protein leak from the liver and the interstitial protein concentration of the intestine, a concept alluded to in the older literature [36,37] but seldom discussed in recent reviews of ascites. This mechanism provides a straight forward explanation for use of the serum-ascites albumin gradient (SAAG) in the differential diagnosis of ascites (see Section IIE).

Since the ascites protein concentration in portal hypertension is only about $1 / 3$ of that of the fluid leaking from the liver, the bulk of ascitic fluid is derived from the intestine rather than the liver. This fluid movement from the intestine into the peritoneum continues as long as the liver continues to leak protein. Homeostasis is achieved when the rising ascitic pressure $\left(\mathrm{P}_{\mathrm{A}}\right)$ increases the rate of peritoneal lymph and protein drainage until it equals the rate at which protein leaks from the liver. Although it has been hypothesized that increased ascites pressure $\left(\mathrm{P}_{\mathrm{A}}\right)$ should slow the rate of liver leak [17], as is discussed below, this should be a small to negligible effect because an increase in $\mathrm{P}_{\mathrm{A}}$ 
should produce a proportional increase in $\mathrm{P}_{\mathrm{L}}$. The crucial parameter characterizing the rate of leakage of fluid from the liver is the value of $\left(\mathrm{P}_{\mathrm{L}}-\mathrm{P}_{\mathrm{A}}\right)$. Experimental measurements of this parameter are discussed in the next section.

\section{Interpretation of experimental hepatic "wedge" and "free" pressure and assessment of the pressure difference across the liver capsule $\left(P_{L}-P_{A}\right)$}

Since sinusoids are leaky to protein, the liver hydrostatic tissue pressure $\left(\mathrm{P}_{\mathrm{L}}\right)$ is nearly equal to the "average" sinusoidal pressure $\left(\mathrm{P}_{\mathrm{S}}\right.$, eq. (7)). The site of the liver flow resistance is controversial, with evidence for both presinusoidal [38] and post-sinusoidal [39] sites. Recent results suggest that the resistance is primarily in the sinusoids and is distributed relatively uniformly along the sinusoidal length both in normal and cirrhotic conditions [40-42]. Using this latter assumption:

$$
P_{S} \approx\left(P_{H V}+P_{P V}\right) / 2 \approx P_{L}
$$

Since direct access to the portal vein requires a laparotomy, virtually all measurements have been obtained indirectly via hepatic vein catheterization. When flow is obstructed via "wedging" of a catheter in a hepatic vein, the measured pressure should equal the portal pressure (assuming no anastomoses between the vessels of the wedged liver segment and vessels with low pressure). Such is the case in cirrhosis, where "wedged" pressure measurements have been shown to equal portal vein pressures [43-46]. The pressure when the catheter is withdrawn to an unwedged ("free") position in a hepatic vein provides a measure of the hepatic vein (or inferior venal cava) pressure $[47,48]$.

$$
P_{\text {Wedge }} \approx P_{P V} \quad P_{\text {Free }} \approx P_{H V}
$$

It is useful to briefly summarize the relations between all the pressures in the portal system (see Figure 1) for the normal condition:

$$
\begin{aligned}
& \text { Normal Relations: } P_{A}<P_{R A}+2 \\
& P_{H V}=P_{R A}+2 \quad P_{P V}=P_{R A}+F_{L} R_{L}+2 \quad P_{C}=P_{R A}+F_{L} R_{L}+5 \\
& P_{S} \approx\left(P_{H V}+P_{P V}\right) / 2 \quad P_{L} \approx P_{S} \quad P_{I} \approx P_{A}
\end{aligned}
$$

where $F_{L}$ and $R_{L}$ are the liver flow and resistance and where the hepatic vein pressure $\left(\mathrm{P}_{\mathrm{HV}}\right)$ is assumed to be about $2 \mathrm{~mm}$ greater than the right atrial pressure $\left(\mathrm{P}_{\mathrm{RA}}\right)$ ([49] and see Table 1) and the intestinal capillary pressure $\left(\mathrm{P}_{\mathrm{C}}\right)$ is about $3 \mathrm{~mm}$ greater than the portal vein pressure $\left(\mathrm{P}_{\mathrm{PV}}\right)[15,50]$. As these relations show, all the pressures in the portal system can be directly related to systemic right atrial pressure and the liver flow and resistance.

There is a dramatic change in these relations if there is gross ascites and the ascites pressure $\left(\mathrm{P}_{\mathrm{A}}\right)$ becomes greater than the normal hepatic vein pressure. Since the hepatic veins (and inferior vena cava) are collapsible, the hepatic vein pressure must be minimally greater than the intra-abdominal pressure, so that $\mathrm{P}_{\mathrm{A}} \approx \mathrm{P}_{\mathrm{HV}} \approx \mathrm{P}_{\text {Free. }}$. Hernriksen et. al. [47] have directly confirmed this relation and shown that $\mathrm{P}_{\text {Free }} \approx \mathrm{P}_{\mathrm{A}}$ over a wide range of pressures in patients with ascites. This condition produces a different set of relations:

$$
\begin{aligned}
& \text { Ascites: } P_{A}>=P_{R A}+2 \\
& P_{H V}=P_{A} \quad P_{P V}=P_{A}+F_{L} R_{L} \quad P_{C}=P_{A}+F_{L} R_{L}+3 \\
& P_{S} \approx\left(P_{H V}+P_{P V}\right) / 2 \quad P_{L} \approx P_{S} \quad P_{I} \approx P_{A}
\end{aligned}
$$

As can be seen, for this condition the portal pressures become linearly dependent on $\mathrm{P}_{\mathrm{A}}$ and are uncoupled from the systemic right atrial pressure. This shift between these two pressure domains, which commonly is ignored, has important implications for interpreting portal pressure measurements (see below). At high peritoneal pressure, all the liver and intestinal pressures become additively dependent on $\mathrm{P}_{\mathrm{A}}$ and changes in $\mathrm{P}_{\mathrm{A}}$ have no effect on the relative pressure relations. This has already been referred to above (Section IIB) when it was concluded that increases in ascitic pressure do not change the value of $\left(\mathrm{P}_{\mathrm{L}}-\mathrm{P}_{\mathrm{A}}\right)$ and therefore do not slow the leak of liver protein. This constancy of $\left(\mathrm{P}_{\mathrm{L}}-\mathrm{P}_{\mathrm{A}}\right)$ as $\mathrm{P}_{\mathrm{A}}$ increases is based on the assumption that the liver flow $\left(F_{L}\right)$ and resistance $\left(R_{L}\right)$ are constant (eq. (13)). In fact, one might expect a small decrease in $F_{L}$ as increases in $\mathrm{P}_{\mathrm{A}}$ and $\mathrm{P}_{\mathrm{PV}}$ leads to increased portal to systemic shunting. This decrease in $F_{L}$ should slightly decrease the value of $\left(\mathrm{P}_{\mathrm{L}}-\mathrm{P}_{\mathrm{A}}\right)$. This prediction is directly supported by the measurements of Luca et. al. [79] of the free and wedge pressure before and after paracentesis. The wedge pressure fell by $7.4 \mathrm{~mm} \mathrm{Hg}$ (31.9-24.5) and there was a nearly equivalent $5.9 \mathrm{~mm}$ $\mathrm{Hg}$ fall in the free pressure with $\mathrm{P}_{\mathrm{L}}-\mathrm{P}_{\mathrm{A}}$ (eq. (15)) decreasing by only $0.85 \mathrm{~mm} \mathrm{Hg}$.

The difference between the wedge and free pressure, the "hepatic vein pressure gradient" $\left(\mathrm{P}_{\mathrm{HVPG}}=\mathrm{P}_{\text {Wedge }}\right.$ $\mathrm{P}_{\text {Free }} \approx \mathrm{P}_{\mathrm{PV}}-\mathrm{P}_{\mathrm{HV}}=\mathrm{F}_{\mathrm{L}} \mathrm{R}_{\mathrm{L}}$ ), is directly proportional to the resistance of the liver to portal flow. Thus, this gradient commonly is employed to characterize the severity of portal hypertension in cirrhotic subjects. $\mathrm{P}_{\mathrm{HVPG}}$ is also used clinically as a surrogate measure of the driving pressure for the formation of ascites. This can be misleading because it ignores the importance of the two pressure domains (eqs. (12) and (13)) discussed above. The critical parameter characterizing the rate of ascites formation is the pressure difference across the liver capsule $\left(\mathrm{P}_{\mathrm{L}}-\mathrm{P}_{\mathrm{A}}\right)$. With low intraperitoneal pressure, this pressure difference (calculated using eq. (12)) equals:

$$
\begin{aligned}
P_{L}-P_{A} & =\left(P_{P V}+P_{H V}\right) / 2-P_{A} \\
& \approx\left(P_{\text {Wedge }}+P_{\text {Free }}\right) / 2-P_{A}
\end{aligned}
$$


Table 1 Hemodynamic responses to drugs in cirrhotic patients

\begin{tabular}{|c|c|c|c|c|c|c|c|c|c|c|c|c|c|c|c|c|c|c|}
\hline \multirow[t]{2}{*}{ Drug } & \multirow{2}{*}{$\begin{array}{l}\Delta \mathrm{t} \\
\text { Hours }\end{array}$} & \multirow{2}{*}{$\begin{array}{l}\text { CO } \\
\text { Pre }\end{array}$} & \multirow[b]{2}{*}{ Post } & \multicolumn{2}{|c|}{$\mathrm{HBF}$} & \multicolumn{2}{|l|}{$P_{\mathrm{RA}}$} & \multicolumn{2}{|c|}{ Wedge } & \multicolumn{2}{|c|}{ Free } & \multicolumn{2}{|c|}{$P_{\text {HVPG }}$} & \multicolumn{2}{|c|}{ Resistance } & \multicolumn{2}{|c|}{$\Delta\left(\mathrm{P}_{\mathrm{L}}-\mathrm{P}_{\mathrm{A}}\right)$} & \multirow[t]{2}{*}{ Comments } \\
\hline & & & & Pre & Post & Pre & Post & Pre & Post & Pre & Post & Pre & Post & Pre & Post & $\begin{array}{l}\text { Eq. } \\
16\end{array}$ & $\begin{array}{l}\text { Eq. } \\
17\end{array}$ & \\
\hline \multicolumn{19}{|c|}{ Spironolactone } \\
\hline [51] & 1440 & 8.6 & 7.3 & 1.33 & 1.24 & 3.5 & 1.8 & 23.9 & 20.8 & 6.4 & 5.5 & 17.6 & 15.3 & 13.2 & 12.3 & 2.0 & 1.15 & No ascites \\
\hline [52] & 168 & 6.75 & NR & NR & & NR & & 26.3 & 23.5 & 9.8 & 10.6 & 16.5 & 12.9 & NR & NR & 1.0 & 1.8 & $70 \%$ ascites \\
\hline [53] & 672 & 6.48 & 5.76 & 1.00 & 1.00 & NR & & 18.7 & 15.7 & 2.2 & 2.8 & 16.5 & 12.9 & 16.5 & 12.9 & 1.2 & 1.8 & No ascites \\
\hline [54] & 1344 & 5.5 & 4.9 & 1.0 & 0.94 & NR & & 22.4 & 20.1 & 4.9 & 4.4 & 17.5 & 15.7 & 17.5 & 16.7 & 1.4 & 0.9 & $\begin{array}{l}\text { No ascites, } \\
\text { unrestricted } \mathrm{Na}^{+}\end{array}$ \\
\hline \multicolumn{19}{|c|}{ Furosemide } \\
\hline [53] & 672 & 8.4 & 6.78 & 1.29 & 1.08 & NR & & 17.6 & 16.7 & 3.9 & 3.1 & 13.7 & 13.6 & 10.6 & 12.5 & 0.85 & 0.05 & No ascites \\
\hline [55] & 1 & 6.6 & 5.5 & 1.49 & 0.82 & 5 & 3 & 31.1 & 27.7 & 9.0 & 8.2 & 22.1 & 19.5 & 14.8 & 23.8 & 2.1 & 1.3 & $\begin{array}{l}\text { Acute affect, } 60 \% \\
\text { ascites }\end{array}$ \\
\hline \multicolumn{19}{|c|}{ Propranolol } \\
\hline [56] & 1 & 7.6 & 5.9 & 1.06 & 0.862 & 3.7 & 5.5 & 23.8 & 22.9 & 5.7 & 7.0 & 18.1 & 15.9 & 17.1 & 18.4 & -0.2 & 1.1 & $\begin{array}{l}\text { Varices and/or } \\
\text { ascites }\end{array}$ \\
\hline [57] & 240 & 8.13 & 5.36 & 1.5 & 1.8 & NR & & 29.7 & 26.9 & 8.6 & 10.1 & 21.1 & 16.8 & 14.1 & 9.3 & 0.65 & 2.15 & $45 \%$ ascites \\
\hline [58] & 672 & 6.05 & 5.0 & 0.93 & 0.826 & 1.9 & 1.1 & 19.3 & 14.5 & 3.6 & 3.2 & 15.1 & 11.4 & 16.2 & 13.8 & 2.6 & 1.85 & No ascites \\
\hline [59] & $1 / 4$ & 6.33 & 5.01 & NR & & NR & & 27.9 & 25.7 & 7.0 & 8.0 & 20.9 & 17.7 & NR & NR & 0.6 & 1.6 & Mild-6\% ascites \\
\hline [59] & $1 / 4$ & 7.17 & 5.76 & NR & & NR & & 31.3 & 29.2 & 7.1 & 8.4 & 24.2 & 20.8 & NR & NR & 0.4 & 1.7 & $\begin{array}{l}\text { Moderate-72\% } \\
\text { ascites }\end{array}$ \\
\hline [59] & $1 / 4$ & 9.03 & 5.92 & NR & & NR & & 32.1 & 29.6 & 8.8 & 9.5 & 23.4 & 20.1 & NR & NR & 0.9 & 1.65 & $\begin{array}{l}\text { Severe-100\% } \\
\text { ascites }\end{array}$ \\
\hline$[60]$ & 1848 & 7.6 & 5.8 & 1.25 & 1.01 & 5.8 & 6.4 & 28.8 & 25.9 & 8.5 & 8.3 & 20.3 & 17.6 & 16.2 & 17.4 & 1.55 & 1.35 & Varices, $P_{\text {HVPG }}>12$ \\
\hline [61] & 2160 & NR & & NR & & NR & & 27.5 & 26.0 & 10.0 & 13.9 & 17.3 & 12.1 & NR & NR & -1.2 & 2.6 & $100 \%$ variceal bleec \\
\hline [62] & 336 & NR & & NR & & 8.8 & 12.2 & 34.5 & 32.7 & 15.8 & 17.1 & 18.7 & 15.45 & $N R$ & NR & 0.25 & 1.63 & $75 \%$ ascites \\
\hline \multicolumn{19}{|c|}{ Timolol } \\
\hline [63] & 1 & NR & & NR & & NR & & 24.9 & 23.6 & 8.4 & 10.0 & 16.5 & 14.4 & NR & NR & -0.15 & 1.05 & $100 \%$ varices \\
\hline \multicolumn{19}{|c|}{ Carvedilol } \\
\hline$[60]$ & 1848 & 7.5 & 6.4 & 1.39 & 1.28 & 4.6 & 5.5 & 26.4 & 23.5 & 7.3 & 8.2 & 19.0 & 15.2 & 13.7 & 11.9 & 1.0 & 1.9 & Varices, $\mathrm{P}_{\mathrm{HVPG}}>12$ \\
\hline \multicolumn{19}{|c|}{ Clonidine } \\
\hline [64] & 168 & 6.41 & 5.40 & 1.05 & 1.33 & 5.2 & 3.4 & 30.4 & 27.4 & 10.2 & 9.7 & 20.1 & 17.6 & 19.1 & 13.2 & 1.75 & 1.25 & 100\% Ascites \\
\hline [65] & $3 / 4$ & 6.40 & 5.36 & 0.96 & 1.22 & NR & & 31.3 & 28 & 11.0 & 11.4 & 20.3 & 16.6 & 21.1 & 13.6 & 1.45 & 1.85 & $100 \%$ Ascites \\
\hline [66] & 448 & 7.8 & 6.7 & 1.2 & 1.1 & 2.6 & 4.2 & 23.9 & 24.6 & 5.1 & 8.7 & 18.8 & 15.9 & 15.7 & 14.4 & -2.15 & 1.45 & $40 \%$ ascites \\
\hline \multicolumn{19}{|c|}{ Nitroglycerin } \\
\hline [67] & $\approx 1 / 10$ & NR & & NR & & NR & & 22.5 & 18.9 & 4.6 & 3.6 & 17.9 & 15.1 & NR & NR & 2.3 & $1 / 4$ & Sublingual \\
\hline [68] & 1 & NR & & 0.93 & 0.919 & NR & & 26.0 & 22.1 & 8.4 & 8.6 & 17.6 & 13.6 & NR & NR & 1.85 & 2 & Transdermal \\
\hline [69] & $1 / 3$ & 7.42 & 6.75 & 1.34 & 1.1 & 6.1 & 4.0 & 29.2 & 29.3 & 8.3 & 8.2 & 20.9 & 21.1 & 15.7 & 14.4 & 0 & 00.1 & $\begin{array}{l}\text { Low dose IV, 53\% } \\
\text { ascites }\end{array}$ \\
\hline Vasopr & & & & & & & & & & & & & & & & & & \\
\hline [70] & $1 / 2$ & NR & & NR & & NR & & 28.6 & 24.0 & 5.7 & 6.3 & 22.9 & 17.7 & NR & NR & 2.0 & 2.6 & $\begin{array}{l}\text { Bleeding varices, } \\
40 \% \text { ascites }\end{array}$ \\
\hline [71] & $1 / 2$ & 7.6 & 6.5 & 1.89 & 1.06 & 5.0 & 7.5 & 26.6 & 23.6 & 7.6 & 9.1 & 19.0 & 14.6 & 10.1 & 13.8 & 0.75 & 2.2 & 30 min IV inf \\
\hline [72] & $1 / 2$ & 7.14 & 5.77 & 1.35 & 0.91 & NR & & 17.8 & 12.7 & 6.7 & 7.3 & 11.1 & 5.4 & 8.22 & 5.93 & 2.25 & 2.85 & $40 \%$ ascites, IV inf \\
\hline Terlipre & & & & & & & & & & & & & & & & & & \\
\hline [73] & 1 & NR & NR & NR & NR & 5.2 & 9 & 25.4 & 25.0 & 6.0 & 8.1 & 19.4 & 16.8 & NR & NR & -0.85 & 1.3 & $\begin{array}{l}\text { Variceal gradient } \\
\text { reduction }\end{array}$ \\
\hline Captop & & & & & & & & & & & & & & & & & & \\
\hline [74] & 504 & NR & & NR & & NR & & 22.9 & 20.7 & 15.0 & 12.1 & 7.58 & 9.32 & NR & NR & 2.55 & -0.5 & $100 \%$ ascites \\
\hline [61] & 2160 & NR & & NR & & NR & & 24.8 & 21.1 & 9.3 & 7.1 & 15.6 & 13.0 & NR & NR & 2.95 & 1.3 & $100 \%$ variceal bleec \\
\hline
\end{tabular}


Table 1 Hemodynamic responses to drugs in cirrhotic patients (Continued)

\begin{tabular}{|c|c|c|c|c|c|c|c|c|c|c|c|c|c|c|c|c|c|c|}
\hline \multicolumn{19}{|c|}{ Enalaprilat } \\
\hline [75] & $1 / 2$ & 6.7 & 6.9 & NR & & NR & & 32.1 & 25.6 & 11.2 & 10.8 & 21.0 & 16.1 & NR & NR & 3.45 & 2.45 & IV infusion \\
\hline \multicolumn{19}{|c|}{ Losartan } \\
\hline [62] & 336 & NR & & NR & & 8.4 & 8.55 & 32.4 & 28.31 & 13.21 & 14.26 & 19.21 & 14.15 & NR & NR & 1.53 & 2.53 & $63 \%$ ascites \\
\hline [76] & & 5.8 & 5.7 & NR & & NR & & 20.3 & 17.3 & 4.9 & 3.7 & 15.4 & 13.6 & NR & NR & 2.1 & 0.9 & Pre-ascitic, 4 week \\
\hline \multicolumn{19}{|c|}{ Saralasin } \\
\hline [77] & $\approx 1 / 2$ & 6.5 & 5.97 & 1.42 & 1.35 & 4.8 & 4.3 & 28 & 24.0 & 10.8 & 10.2 & 17.2 & 13.78 & 12.1 & 10.2 & 2.31 & 1.71 & $100 \%$ ascites, IV inf \\
\hline \multicolumn{19}{|c|}{ Somatostatin } \\
\hline [72] & $1 / 2$ & 6.59 & 6.38 & 3.7 & 1.1 & 0.89 & 4.1 & 19.5 & 16.2 & 7.2 & 7.6 & 12.3 & 8.6 & 3.32 & 7.82 & 1.45 & 1.85 & $40 \%$ ascites, IV inf \\
\hline \multicolumn{19}{|c|}{ Fenoldopam } \\
\hline [78] & 1 & 8.9 & 10.5 & 1.5 & 1.6 & 6.1 & 4.4 & 24.6 & 28.0 & 9.2 & 8.7 & 15.4 & 19.3 & 10.23 & 12.1 & -1.45 & -1.95 & $\begin{array}{l}\text { MAP: 84.6-61.8 } \\
\text { decrease }\end{array}$ \\
\hline
\end{tabular}

$\Delta \mathrm{t}=$ time interval pre-post (hours), $\mathrm{CO}=$ cardiac output (liters/min), HBF = hepatic blood flow (liters $/ \mathrm{min}$ ), $\mathrm{P}_{\mathrm{RA}}=$ right atrial pressure (mm Hg),

Wedge $=$ portal wedge pressure $(\mathrm{mm} \mathrm{Hg})$, Free $=$ free portal pressure $(\mathrm{mm} \mathrm{Hg}), \mathrm{P}_{\mathrm{HVPG}}=$ Wedge - Free, Resistance $=$ hepatic flow resistance $=\mathrm{Gradient} / \mathrm{HBF}(\mathrm{mm}$ $\mathrm{Hg} / \mathrm{liter})$,

$\Delta\left(P_{L}-P_{A}\right)=$ change in pressure difference across the liver capsule-(pre - post), MAP = mean arterial pressure

For the case of high intraperitoneal pressure (that occurs with appreciable ascites), $\mathrm{P}_{\mathrm{HV}}=\mathrm{P}_{\mathrm{A}} \approx \mathrm{P}_{\text {Free }}$ (eq. (13)) and $\left(\mathrm{P}_{\mathrm{L}}-\mathrm{P}_{\mathrm{A}}\right)$ is described by:

$$
\begin{aligned}
P_{L}-P_{A} & =\left(P_{P V}+P_{H V}\right) / 2-P_{A}=\left(P_{P V}+P_{A}\right) / 2-P_{A} \\
& \approx\left(P_{\text {Wedge }}-P_{\text {Free }}\right) / 2=P_{H V P G} / 2
\end{aligned}
$$

It is only for this latter case that $\left(\mathrm{P}_{\mathrm{L}}-\mathrm{P}_{\mathrm{A}}\right)$ is directly determined by $\mathrm{P}_{\text {HVPG }}$. In the absence of gross ascites, determination of $\left(\mathrm{P}_{\mathrm{L}}-\mathrm{P}_{\mathrm{A}}\right)$ requires an estimate of ascites pressure (which usually is neglected in most studies of portal hemodynamics). Recognition of the importance of the two pressure domains and correctly calculating $\left(\mathrm{P}_{\mathrm{L}}-\mathrm{P}_{\mathrm{A}}\right)$ is crucial since, as will be shown, minor differences (several $\mathrm{mm} \mathrm{Hg}$ ) in pressure may determine the presence or absence of ascites. The discussion of the action of $\beta$-blockers (Section IIF) provides an illustration of the importance of the difference between calculations based on eq. 14 versus eq. 15 .

In subjects with normal livers, $\mathrm{P}_{\mathrm{Wedge}}$ and $\mathrm{P}_{\text {Free }}$ are about 6 and $4 \mathrm{~mm} \mathrm{Hg}$, respectively [80-82]. Since direct measurement of $\mathrm{P}_{\mathrm{A}}$ in normal subjects with no overt ascites is difficult, indirect approaches have been employed [83]. Using the urinary bladder measurements, Cobb et. al. [14] reported values of about $2 \mathrm{~mm} \mathrm{Hg}$ for $\mathrm{P}_{\mathrm{A}}$ in the normal supine subject. Substituting this value into eq. (14), yields a $\left(\mathrm{P}_{\mathrm{L}}-\mathrm{P}_{\mathrm{A}}\right)$ of about $3 \mathrm{~mm} \mathrm{Hg}$ for normal subjects. Estimates of the value of $\left(\mathrm{P}_{\mathrm{L}}-\mathrm{P}_{\mathrm{A}}\right)$ in ascites subjects is uncertain because, as discussed above, investigators have failed to distinguish between the two pressure domains and direct measurements of $\mathrm{P}_{\mathrm{A}}$ are not available. There is a weak correlation between $\mathrm{P}_{\text {HVPG }}$ and the presence or absence of ascites. In 3 studies of $\mathrm{P}_{\text {HVPG }}$ in cirrhotic patients, the average values in subjects without versus with ascites were 11.5 vs 16
[84]; 17.7 vs 19.1 [85] and 14.9 vs $17.8 \mathrm{~mm} \mathrm{Hg}$ [86]. In a prospective follow up of 122 cirrhotics undergoing a TIPS procedure, Casado et. al. [87] reported that ascites was a problem only in patients whose $P_{\text {HVPG }}$ remained greater than $12 \mathrm{~mm} \mathrm{Hg}$. Substituting this value into eq. (15), indicates that the value of $\mathrm{P}_{\mathrm{L}}-\mathrm{P}_{\mathrm{A}}$ must be at least $6 \mathrm{~mm} \mathrm{Hg}$ (twice the normal value) before appreciable ascites is formed. This observation supports the assumption in our model that there is a critical value of $\mathrm{P}_{\mathrm{L}}-\mathrm{P}_{\mathrm{A}}$ above which the liver capsule and/or lymphatics rupture, allowing leakage of high protein tissue fluid into the peritoneal space.

\section{Intra-abdominal lymph drainage (Jlymph)}

The volume of ascites reaches a steady-state when the rate of leakage of protein from the liver equals the rate of protein removal by lymph. Most of the peritoneal cavity is drained via diaphragmatic lymphatics that drain into the right lymph duct. These lymphatics have complex stomatal openings on the peritoneal surface that provide fixed drainage sites [19]. These drainage sites are like holes in a balloon and, unlike the hepatic vein or inferior vena cava, cannot be collapsed by high intraperitoneal pressure. Since it is not possible to directly measure this lymph flow, indirect methods have been employed. The standard approach is to measure the kinetics of removal of labeled albumin from peritoneal fluid. A major area of controversy in the peritoneal dialysis literature is the interpretation of these measurements since the rate of disappearance of label from peritoneal fluid seemingly is about 10 times greater than the rate of appearance of this label in plasma $[88,89]$ due to sequestration of the albumin in tissue. The weight of evidence suggests that lymph flow should be determined from the rate of appearance of the peritoneal label in plasma. This rate $\left(\mathrm{J}_{\text {lymph }}\right)$ is 
only about $10 \mathrm{ml} /$ hour when 2 liters of fluid is instilled during peritoneal dialysis $[90,91]$. Henriksen et. al. $[92,93]$ have shown that in patients with cirrhotic ascites, Jlymph is much greater, about $50-60 \mathrm{ml} /$ hour. The factors responsible for this increased lymph flow are not well understood. These patients had greater pressures $\left(\mathrm{P}_{\text {Free }}\right.$ of about $12 \mathrm{~mm} \mathrm{Hg}$ ) and ascitic volumes (about 7 liters) than the dialysis patients which may account for the difference. Zink and Greenway [94] have shown in cats that peritoneal fluid and protein absorption had an approximately linear dependence on pressure.

It is well established that cirrhotic patients can be in a steady state with roughly constant ascites volumes for long time periods. This implies that as ascites volume increases, there must be some compensating effect that produces a balance between the rate of protein leak and removal. As discussed above, a rise in $\mathrm{P}_{\mathrm{A}}$ should not have a marked effect on the protein leak rate determined by $\left(\mathrm{P}_{\mathrm{L}}-\mathrm{P}_{\mathrm{A}}\right)$ since this increase in $\mathrm{P}_{\mathrm{A}}$ produces an equivalent increase in $\mathrm{P}_{\mathrm{L}}$. Thus, the homeostatic mechanism presumably is that an increase in $\mathrm{P}_{\mathrm{A}}$ increases $\mathrm{J}_{\text {lymph }}$ as has been experimentally observed in cats [94]. Quantitative support for this in humans is provided by the measurements of Shear et. al. [95] of the rate of formation of ascites following paracentesis. If one assumes that the rate of lymph flow was $60 \mathrm{ml} /$ hour pre-paracentesis (see above) and $10 \mathrm{ml} /$ hour postparacentesis (as observed in dialysis patients), the predicted net rate of ascites formation immediately after paracentesis would be about $50 \mathrm{ml} /$ hour (1.2 liters/day), which is similar to what was observed by Shear et. al. [95]. However, this is indirect evidence and, although lymph flow must balance protein leak at steady state, the exact rate of this flow in various situations needs further study.

\section{E. Protein concentration in ascitic fluid and the serum- ascites albumin gradient (SAAG)}

The model predicts that 1) hepatic lymph protein should be approximately equal to plasma protein (eq. (7)); 2) as the liver sinusoidal pressure is raised, a concomitant rise in intestinal capillary pressure should wash down the protein concentration in the intestinal tissue; and 3) ascitic fluid protein should approximately equilibrate with this washed down intestinal tissue protein (eq. (8)) (which equals intestinal lymph protein). A corollary of predictions 2 and 3 is that as the severity of portal hypertension increases, which causes an increasing intestinal capillary pressure and decreasing intestinal tissue protein, the ascitic fluid protein concentration should also fall. Witte et. al. [13] measured the protein concentration in ascites fluid and hepatic and intestinal lymph in patients in varying stages of ascites. The measured lymph protein/plasma total protein ratios were: control: hepatic $=0.88$; intestinal $=0.7$; early stage cirrhosis: hepatic $=0.8$, intestine $=0.8$, ascites $=0.65$; late stage: hepatic $=0.6$; intestine $=0.12$; ascites $=0.17$. These experimental observations are in qualitative agreement with the above predictions. An important differential diagnostic marker of ascites is the value of the serum-ascites albumin gradient (SAAG). A SAAG of $\geq 1.1 \mathrm{gm} \%$ is strongly indicative of portal hypertension (either cirrhotic or cardiac ascites) while all other causes of ascites (e.g. infections, malignancy) tend to have smaller gradients [96]. While the diagnostic accuracy of the SAAG has been demonstrated empirically, the physiology underlying this measurement has received little attention. The values of the SAAG in various conditions follow directly from the assumption in the model that intestinal tissue and ascites fluid have similar albumin concentrations (eq. (8)). In subjects with normal portal pressure these concentrations are high, about $70 \%$ of the plasma value, resulting in a low SAAG. In contrast, the increase in intestinal capillary hydrostatic pressure and the accompanying wash down of intestinal interstitial protein produced by portal hypertension of any etiology results in low ascites protein concentrations, hence a high SAAG.

Although the above discussion is focused primarily on cirrhotic ascites, cardiac ascites is also associated with a SAAG of $\geq 1.1 \mathrm{gm} \%$. In a series of patients with chronic hepatopathy ( $68 \%$ with ascites), the average value of the free hepatic vein pressure was $17 \mathrm{~mm} \mathrm{Hg}$, with a $\mathrm{P}_{\mathrm{HVPG}}$ of $2 \mathrm{~mm} \mathrm{Hg}$ [97]. Thus, the liver sinusoidal pressure is about $18 \mathrm{~mm} \mathrm{Hg}$ which, presumably, results in rupture of liver lymphatics and leakage of protein into the peritoneal space. The corresponding intestinal capillary pressure is about $22 \mathrm{~mm} \mathrm{Hg}(3 \mathrm{~mm} \mathrm{Hg}$ greater than portal vein pressure) which should wash down intestinal tissue albumin to a low value. Osmotic equilibration of the ascitic albumin with this intestinal tissue results in a large SAAG.

\section{F. Medical treatment of ascites}

Given the widespread use of diuretics to treat ascites, it is surprising that the mechanism of benefit of these drugs has received little attention. The challenge is relating the systemic effects of diuretics (alterations in blood pressure, blood volume, systemic resistance and capacitance, etc.) to the two local primary factors that determine ascites volume in the above model: 1 ) protein leak from the liver surface as a result of increased $\left(\mathrm{P}_{\mathrm{L}}-\mathrm{P}_{\mathrm{A}}\right)$ and 2) intra-abdominal lymph drainage. In this section we will compare the hemodynamic actions of diuretics that alleviate ascites, with the actions of a number of other drugs that have been evaluated for potential utility in the treatment of portal hypertension

Table 1 summarizes the reported hemodynamic changes produced by 15 different drugs in cirrhotic 
subjects. As discussed above (Section IIC), there are two different relationships for $\left(\mathrm{P}_{\mathrm{L}}-\mathrm{P}_{\mathrm{A}}\right)$, depending on whether there is no ascites and the intra-abdominal pressure $\left(\mathrm{P}_{\mathrm{A}}\right)$ is assumed to be small (eq. (14)) or there is appreciable ascites with an increased $\mathrm{P}_{\mathrm{A}}$ (eq. (15)). The penultimate column in Table 1 lists the calculated drug-induced changes in $\left(\mathrm{P}_{\mathrm{L}}-\mathrm{P}_{\mathrm{A}}\right)$ for both of these cases using the following equations:

$$
\begin{aligned}
& \Delta\left(P_{L}-P_{A}\right)=\left(P_{\text {Hep Walge }}^{\text {pre }}+P_{\text {Hepree }}^{\text {pre }}-P_{\text {Hep Weadge }}^{\text {post }}-P_{\text {Heppree }}^{\text {post }}\right) / 2 \quad \text { No ascites } \\
& \Delta\left(P_{L}-P_{A}\right)=\left(P_{H P V G}^{p r e}-P_{H P V G}^{\text {post }}\right) / 2
\end{aligned}
$$

where it is assumed for eq. (16) that the drug does not change the intra-abdominal pressure. For most of the studies listed in Table 1 there was either no or mild ascites, and eq. (16) should be used. Also listed in Table 1 is the change in the hepatic blood flow $\left(\mathrm{F}_{\mathrm{L}}\right)$, the gradient $\left(\mathrm{P}_{\mathrm{HVPG}}\right)$, the corresponding liver resistance $\left(\mathrm{R}_{\mathrm{L}}=\right.$ $\left.\mathrm{P}_{\mathrm{HVPG}} / \mathrm{F}_{\mathrm{L}}\right)$ and the right atrial pressure $\left(\mathrm{P}_{\mathrm{RA}}\right)$.

The administration of the spironolactone or furosemide decreased $\mathrm{P}_{\mathrm{HVPG}}$ by about 20\% [51-55] (Table 1). This decrease primarily resulted from a decrease in the wedge pressure whereas there was only a small change in free hepatic pressure. This decrease in $P_{\text {HVPG }}$ was roughly proportional to the decreased hepatic blood flow; hence there was little change in hepatic resistance. It is also notable that, in the two studies where right atrial pressure was measured, the diuretics produced about a $2 \mathrm{~mm} \mathrm{Hg}$ fall in pressure. In summary, the alterations in local peritoneal fluid balance induced by diuretic therapy presumably are the result of two major systemic changes: 1) a decrease in cardiac output with a corresponding fall in hepatic blood flow and $\mathrm{P}_{\mathrm{HVPG}}$, and 2) a decrease in right atrial pressure.

Administration of non-selective beta blockers (propranolol, timolol, carvediol), cause reductions in $\mathrm{P}_{\mathrm{HVPG}}$ comparable to that observed with diuretics (Table 1). However, beta blockers are not considered useful for the treatment of ascites, and Rector and Reynolds [98] have shown that the addition of propranolol to diuretic therapy reduces renal sodium excretion and may interfere with the action of diuretics. On the other hand, betablockers consistently have been demonstrated to reduce the incidence of bleeding from esophageal varices whereas no such benefit has been noted with diuretics. Surprisingly, there has been little discussion of this paradoxical difference in efficacy of diuretics versus betablockers in the treatment of complications of portal hypertension, given that both classes of drugs seemingly produce similar reductions in portal hemodynamics as measured by the $\mathrm{P}_{\mathrm{HVPG}}$. An important difference between the action of these drugs is that in marked contrast to diuretics, about $50 \%$ of the decrease in $\mathrm{P}_{\mathrm{HVPG}}$ induced with beta blockers results from an increase in the free hepatic pressure (Table 1). Thus the estimated decrease in $\left(\mathrm{P}_{\mathrm{L}}-\mathrm{P}_{\mathrm{A}}\right)$ using eq. (16) is less than half that observed with diuretics. Again, the local changes can be directly associated with the systemic effects, with the decrease in the gradient explained by the decrease in cardiac output and hepatic blood flow (with negligible change in resistance) and the increase in the free portal pressure explained by the increased right atrial pressure. These data demonstrate why $\mathrm{P}_{\mathrm{HVPG}}$ is not directly correlated with $\left(\mathrm{P}_{\mathrm{L}}-\mathrm{P}_{\mathrm{A}}\right)$ in patients without gross ascites. For example, a drug that increased the free hepatic pressure but had no effect on the wedge pressure would decrease $\mathrm{P}_{\mathrm{HVPG}}$ but would actually increase $\left(\mathrm{P}_{\mathrm{L}}-\mathrm{P}_{\mathrm{A}}\right)$ according to eq. (16). It has been shown that the development of varices or variceal hemorrhage is strongly correlated with both the absolute value of $\mathrm{P}_{\mathrm{HVPG}}$ [99] and the response of $\mathrm{P}_{\mathrm{HVPG}}$ to beta blockers [48]. For varices, the important parameter is the difference between the portal vein pressure and the pressure in the shunted systemic vein. One would expect that $P_{\text {HVPG }}$ should be a good approximation of this pressure difference. Thus, $\mathrm{P}_{\mathrm{HVPG}}$ may influence the tendency to bleeding from varices, even though this pressure gradient does not directly correlate with $\left(\mathrm{P}_{\mathrm{L}}-\mathrm{P}_{\mathrm{A}}\right)$, which is the crucial parameter for the development of ascites.

Clonidine, an $\alpha_{2}$ receptor agonist, is unique among the 15 drugs in Table 1 in that its major action seems to be a decrease in hepatic resistance which produces a corresponding decrease in $\mathrm{P}_{\mathrm{HVPG}}$ with little change in hepatic blood flow [64-66]. In clinical trials of clonidine for the treatment of ascites, clonidine by itself was not effective but the combination of clonidine and spironolactone produced a greater weight loss and ascites decrease than spironolactone alone [100]. Because clonidine does not decrease portal blood flow, it is not regarded as an effective treatment for gastroesophageal varices $[101,102]$

Also listed in Table 1 are the portal hemodynamic responses to nine other drugs. The activation of the renin-angiotensin-aldosterone (RAAS) system has a central role in the standard "forward theory" of ascites formation [6]. The RAAS antagonists in Table 1 (captopril, enalapril, losartin, saralasin) reduce $\mathrm{P}_{\mathrm{HVPG}}$ with little or no change in $\mathrm{P}_{\text {Free. }}$. A recent systematic meta-analysis of the RAAS antagonists concluded that the $\mathrm{P}_{\text {HVPG }}$ response was a function of the Child Pugh class [103]. Despite this decrease in $\mathrm{P}_{\mathrm{HVPG}}$, ACE inhibitors do not seem to be of benefit in the treatment of ascites [104]. Although vasopressin and terlipressin (vasopressin agonist) decreased $\mathrm{P}_{\mathrm{HVPG}}$, this decrease resulted primarily from an increase in $\mathrm{P}_{\mathrm{RA}}$ and $\mathrm{P}_{\text {Free }}$ (Table 1) and, therefore, they are unlikely to be beneficial in the treatment of ascites. The most recent candidate drug classes for 
the treatment of ascites are the vasopressin V2 receptor antagonists (vaptans). These drugs increase plasma sodium by increasing solute free water excretion and it was hoped they would be useful in ascites. Although short term trials of satavaptan suggested a positive effect, a recent long term randomized trial concluded that it is not beneficial in the treatment of ascites [105]. It is clear from the results in Table 1 that one cannot explain the therapeutic action of diuretics based only on the reduction of $P_{\text {HVPG }}$ since many other drugs that apparently are not effective in the treatment of ascites have similar actions on $\mathrm{P}_{\mathrm{HVPG}}$.

Serum albumin concentration commonly is decreased in cirrhosis. The resultant fall in plasma oncotic pressure is only partially offset by the increased in serum globulins observed in cirrhosis. The use of albumin infusion for the treatment of ascites is controversial. In a comprehensive review of this literature, Trotter et. al. [106] concluded that, although short term therapy (11 to 16 days) was not useful, there was suggestive evidence that long duration albumin infusion (27 days to 2 years) in association with diuretics was beneficial in terms of ascites resolution and ascites redevelopment. In the only controlled trial of albumin in the treatment of ascites, Gentilini et. al. [107] found that addition of albumin to diuretic therapy resulted in a statistically significant increase in the number of responders and significantly reduced the redevelopment of ascites. The interpretation of these results is complicated because albumin also has systemic renal and cardiovascular effects. For example, albumin infusions may increase blood volume and central venous pressure which would increase $\left(\mathrm{P}_{\mathrm{L}}-\mathrm{P}_{\mathrm{A}}\right)$ and exacerbate the ascites. The effects of albumin predicted by our model are small because any change in the amount of protein leaking from the liver will be roughly balanced by the change in the intestinal tissue protein. The model predicts that albumin would affect ascites formation at very high portal pressures because, as was discussed in Section IIA (see eq. (9)), there is a limit to the intestinal capillary pressure at which Starling force balance can be achieved and this limit is set by the plasma colloid osmotic pressure. Thus, in severe portal hypertension that produces intestinal capillary pressures that approach or exceed plasma oncotic pressure, there should be an increase in the rate of ascites formation with decreasing albumin. The quantitative model discussed in Section III provides predictions of the influence of plasma oncotic pressure on ascites volume over the entire range of portal pressures.

If one assumes that the model presented in this review is correct, then diuretics must act through the two local factors $\left(\mathrm{P}_{\mathrm{L}}-\mathrm{P}_{\mathrm{A}}\right)$ and $\mathrm{J}_{\text {lymph }}$. Diuretics decrease $\left(\mathrm{P}_{\mathrm{L}}-\mathrm{P}_{\mathrm{A}}\right)$ from 1 to $2 \mathrm{~mm} \mathrm{Hg}$, which represents about a $10-20 \%$ decrease from the initial value. Another action of diuretics which stands out from all the other drugs listed in Table 1 is the relatively large decrease in right atrial pressure $\left(\mathrm{P}_{\mathrm{RA}}\right)$. This lowering of $\mathrm{P}_{\mathrm{RA}}$ by spironolactone or furosemide is apparently not dependent on the diuretic action since decreases of 2-5 $\mathrm{mm} \mathrm{Hg}$ have been observed in chronic renal failure patients on hemodialysis $[108,109]$. This decrease in $P_{R A}$, which has not been previous emphasized, has two separate effects on ascites. First, for low peritoneal pressures (eq. (12)), $\mathrm{P}_{\mathrm{L}}$ is additive to $\mathrm{P}_{\mathrm{RA}}$ and a decrease in $\mathrm{P}_{\mathrm{RA}}$ directly reduces $\left(\mathrm{P}_{\mathrm{L}}\right.$ $\mathrm{P}_{\mathrm{A}}$ ) and the liver leak rate. Second, as discussed in more detail in the description of the quantitative model (Section III), this decrease in $\mathrm{P}_{\mathrm{RA}}$ may increase the rate of peritoneal fluid drainage $\left(\mathrm{J}_{\mathrm{lymph}}\right)$. Although the effect of diuretics on protein leak and $\mathrm{J}_{\text {lymph }}$ are relatively small, if, pre-diuretic, the rate of leak and lymph flow are equal and opposite, these small changes can shift the balance and lead to a reduced ascitic volume. In the next section a quantitative model is developed that demonstrates that, under some conditions, these small changes (20\% reduction in $\mathrm{P}_{\mathrm{HVPG}}$ and $3 \mathrm{~mm} \mathrm{Hg}$ reduction in $\mathrm{P}_{\mathrm{RA}}$ ) surprisingly can lead to the complete reabsorption of ascites. We believe that this is the first attempt to provide a mechanistic explanation for the efficacy of diuretics.

\section{Quantitative physical modeling}

This section will present a quantitative model of ascites formation and removal and the influence of various physiological perturbations on the model's predictions. The first part of this analysis assumes that the system is in a steady state with a constant ascites volume. For this case $\mathrm{J}_{\mathrm{I}}$ (eq. (4)) equals $\mathrm{J}_{\mathrm{C}}$ (eq. (1)) and (assuming $\mathrm{P}_{\mathrm{I}}=$ $\mathrm{P}_{\mathrm{A}}$ ) one can express the fluid flux from the blood to the intraperitoneal space as:

$$
\begin{aligned}
& J_{I}=L_{T}\left[\left(P_{C}-P_{A}\right)-\left(\Pi_{P}-\Pi_{A}\right)\right] \\
& L_{T}=L_{I} L_{C} /\left(L_{I}+L_{C}\right)
\end{aligned}
$$

where $\mathrm{L}_{\mathrm{T}}$ is the total blood to peritoneal space hydraulic conductance of the intestine (i.e., the series conductance of the capillary and mesenteric membranes). The model further assumes that the intact liver capsule is impermeable to protein, and fluid flux from the liver into the peritoneal cavity occurs only when a critical pressure difference $\left(=\mathrm{P}_{\text {Break }}\right)$ between liver tissue $\left(\mathrm{P}_{\mathrm{L}}\right)$ and peritoneal space $\left(\mathrm{P}_{\mathrm{A}}\right)$ is reached that results in rupture of the liver lymphatics and/or capsule. Above this break pressure, the rate of flux of fluid from the liver lymphatics into the peritoneal cavity is a function of the difference between the liver tissue and intraperitoneal pressure (for pressure differences greater than $\left.\mathrm{P}_{\text {Break }}\right)$. Thus: 


$$
\begin{aligned}
& J_{L}=L_{L}\left(P_{L}-P_{A}-P_{\text {Break }}\right) P_{L}-P_{A}>P_{\text {Break }} \\
& =0 \quad P_{L}-P_{A}<=P_{\text {Break }}
\end{aligned}
$$

where $\mathrm{L}_{\mathrm{L}}$ is the conductance of the ruptured lymphatics.

The model assumes that lymph flow from the peritoneal cavity is proportional to the difference between the intraperitoneal $\left(\mathrm{P}_{\mathrm{A}}\right)$ and right atrial pressures $\left(\mathrm{P}_{\mathrm{RA}}\right)$ :

$$
\begin{array}{cc}
J_{\text {Lymph }}=L_{Y}\left(P_{A}-P_{R A}+P_{\min }\right) & P_{A}>P_{R A}-P_{\min } \\
=0 & P_{A}<P_{R A}-P_{\min }
\end{array}
$$

where $\mathrm{P}_{\min }$ determines the zero flow rate and will be assumed equal to $2 \mathrm{~mm} \mathrm{Hg}$. The steady state ascites volume requires that the intra-abdominal lymph flow equals the sum of the intestinal plus liver fluxes:

$$
J_{l y m p h}=J_{I}+J_{L}
$$

Also, the total protein leak from the liver must equal the amount removed by the lymph:

$$
m \Pi_{P} J_{L}=\Pi_{A} J_{l y m p h}
$$

where $\mathrm{m}$ is the concentration of protein in the liver exudate as a fraction of the plasma protein $\left(\Pi_{\mathrm{P}}\right)$. It will be assumed that the intestinal capillary pressure $\left(\mathrm{P}_{\mathrm{C}}\right)$ is $3 \mathrm{~mm} \mathrm{Hg}$ greater than the portal vein pressure $\left(\mathrm{P}_{\mathrm{P}}\right)$ and that the hepatic vein pressure $\left(\mathrm{P}_{\mathrm{HV}}\right)$ is either a) $2 \mathrm{~mm}$ greater than the right atrial pressure $\left(\mathrm{P}_{\mathrm{RA}}\right)$ in the absence of gross ascites; or $b$ ) equal $\mathrm{P}_{\mathrm{A}}$ if $\mathrm{P}_{\mathrm{A}}$ is greater than $\left(\mathrm{P}_{\mathrm{RA}}+2\right)$ :

$$
\begin{array}{rlr}
P_{C} & =P_{R A}+P_{H P V G}+5 & P_{A}<P_{R A}+2 \\
& =P_{A}+P_{H P V G}+3 & P_{A}>P_{R A}+2
\end{array}
$$

where the gradient $\mathrm{P}_{\mathrm{HVPG}}$ is the pressure drop across the liver $\left(=\mathrm{P}_{\mathrm{PV}}-\mathrm{P}_{\mathrm{HV}}\right)$. Finally, it will be assumed that the ascites volume is proportional to the ascites pressure:

$$
\text { Volume }=V_{\min }+D *\left[P_{A}-P_{\min }\right]
$$

where $V_{\text {min }}$ is the ascites volume found normally (100 ml) when $\mathrm{P}_{\mathrm{A}}=\mathrm{P}_{\min }=2 \mathrm{~mm} \mathrm{Hg}$ and $\mathrm{D}$ is the peritoneal compliance. Equations (18)-(24) provide a complete steady state description of the system.

Estimates of the values of the above parameters can be obtained by using the following values for a "typical" ascites patient: $\mathrm{P}_{\mathrm{HVPG}}=20 \mathrm{~mm} \mathrm{Hg}$, ascitic hydrostatic pressure $\left(\mathrm{P}_{\mathrm{A}}\right)=10 \mathrm{~mm} \mathrm{Hg}$ [47], ascites osmotic pressure $\left(\Pi_{\mathrm{A}}\right)=30 \%$ of plasma $[47,96]$, an elevated $\mathrm{P}_{\mathrm{RA}}=5$ $\mathrm{mm} \mathrm{Hg}$ (Table 1) and $\mathrm{J}_{\text {lymph }}=55 \mathrm{ml} /$ hour $[92,93]$. It will be assumed that $P_{\text {Break }}=8 \mathrm{~mm} \mathrm{Hg}$ and that the liver exudate has a protein concentration equal to 0.8 (= $\mathrm{m}$ ) of the plasma, similar to the value found for liver lymph [13]. In the following, the equivalent colloid osmotic pressure $(\Pi)$ will be used for the protein concentration, assuming a plasma value $\left(\Pi_{\mathrm{p}}\right)=25 \mathrm{~mm} \mathrm{Hg}$. Using $\mathrm{J}_{\text {lymph }}=55 \mathrm{ml} /$ hour in eq. (20), $\mathrm{L}_{\mathrm{Y}}=7.86 \mathrm{ml} /$ hour $/ \mathrm{mm} \mathrm{Hg}$ (assuming $\mathrm{P}_{\mathrm{RA}}=5$ and $\mathrm{P}_{\min }=2$ ). Diluting the liver exudate protein from a plasma fraction of 0.8 $(=\mathrm{m})$ to the ascites value of 0.3 requires $\mathrm{J}_{\mathrm{L}}=0.375 \mathrm{~J}_{\mathrm{Y}}=$ $20.6 \mathrm{ml} /$ hour and $\mathrm{J}_{\mathrm{I}}=0.625 \mathrm{~J}_{\mathrm{Y}}=34.4 \mathrm{ml} /$ hour. Using the assumed "typical" ascitic pressures $\left(\mathrm{P}_{\mathrm{HV}}=10, \mathrm{P}_{\mathrm{P}}=30\right.$, $\mathrm{P}_{\mathrm{L}}=20$ and $\mathrm{P}_{\mathrm{L}}-\mathrm{P}_{\mathrm{A}}=10 \mathrm{~mm} \mathrm{Hg}$ ), the net driving force above $\mathrm{P}_{\text {Break }}$ is $2 \mathrm{~mm} \mathrm{Hg}$, corresponding to an $\mathrm{L}_{\mathrm{L}}=10.3$ $\mathrm{ml} /$ hour $/ \mathrm{mm} \mathrm{Hg}$ (eq. (19)). Using these pressures and a $\Pi_{\mathrm{P}}$ of $25 \mathrm{~mm} \mathrm{Hg}$ in eq. (18), the value of the "intestinal" ultrafiltration coefficient $=\mathrm{L}_{\mathrm{T}}=6.25 \mathrm{ml} / \mathrm{hour} / \mathrm{mm} \mathrm{Hg}$. The peritoneal dialysis literature [110] uses a value for $\mathrm{L}_{\mathrm{T}}$ of $4.5 \mathrm{ml} /$ hour $/ \mathrm{mm} \mathrm{Hg}$ for a 2 liter exchange volume. The exchange surface would be larger for the 5 to 10 liter ascitic volumes that are common in ascites patients. Thus, a somewhat higher $\mathrm{L}_{\mathrm{T}}(6.25 \mathrm{ml} /$ hour/ $\mathrm{mmHg}$ ) was employed in the model. Finally, a compliance of the peritoneal cavity (D) of 0.8 liters $/ \mathrm{mm} \mathrm{Hg}$ will be used, based on experimental measurements in humans of the changes in peritoneal pressure following paracentesis $[111,112]$.

Figure 2 shows the steady state peritoneal volume (top), protein concentration (middle) and lymph flow as the $P_{\text {HVPG }}$ varies from $6 \mathrm{~mm} \mathrm{Hg}$ (the pressure when liver exudation starts) to $25 \mathrm{~mm} \mathrm{Hg}$. At a gradient of $18.15 \mathrm{~mm} \mathrm{Hg}$, there is shift between the low pressure domain where $\mathrm{P}_{\mathrm{HV}}=\mathrm{P}_{\mathrm{RA}}+2$, and the high ascitic pressure domain where $\mathrm{P}_{\mathrm{HV}}=\mathrm{P}_{\mathrm{A}}$ (eq. (23)). The ascites protein concentration is expressed in terms of its equivalent colloid osmotic pressure. (For a normal subject with $\mathrm{P}_{\mathrm{HVPG}}=2, \mathrm{P}_{\mathrm{A}}=2, \mathrm{P}_{\mathrm{RA}}=2, \mathrm{P}_{\mathrm{HV}}=4$, the osmotic activity of the steady state ascites protein concentration should be about $20 \mathrm{~mm} \mathrm{Hg}$.) The ascites protein stays in a rather narrow range, falling from about $11 \mathrm{~mm} \mathrm{Hg}$ when the ascites fluid begins to form, to a minimum of about $7 \mathrm{~mm} \mathrm{Hg}$ at $\mathrm{P}_{\mathrm{HVPG}}$ of $18 \mathrm{~mm} \mathrm{Hg}$ and then slowly rising to about $8 \mathrm{~mm} \mathrm{Hg}$. Assuming an albumin/total protein fraction of 0.65 , these values correspond to albumin concentrations of about 2.5, 1.75 and $1.95 \mathrm{gm} \%$ respectively [113]. For the assumed plasma colloid osmotic pressure of $25 \mathrm{~mm} \mathrm{Hg}$ (albumin concentration of $4.45 \mathrm{gm} \%$ ), these values correspond to a SAAG of $1.95,2.75$ and $2.5 \mathrm{gm} \%$. The fall in ascites protein results from the wash down of intestinal tissue protein as the capillary blood pressure increases. At high $P_{\text {HVPG }}$ the leak of high protein fluid from the liver makes a relatively greater contribution to the total ascitic fluid formation, producing the increase in the ascitic protein concentration.

It is of interest to see how the ascites volume is altered by the hemodynamic changes produced by diuretics. As indicated in Table 1, diuretics reduce both 

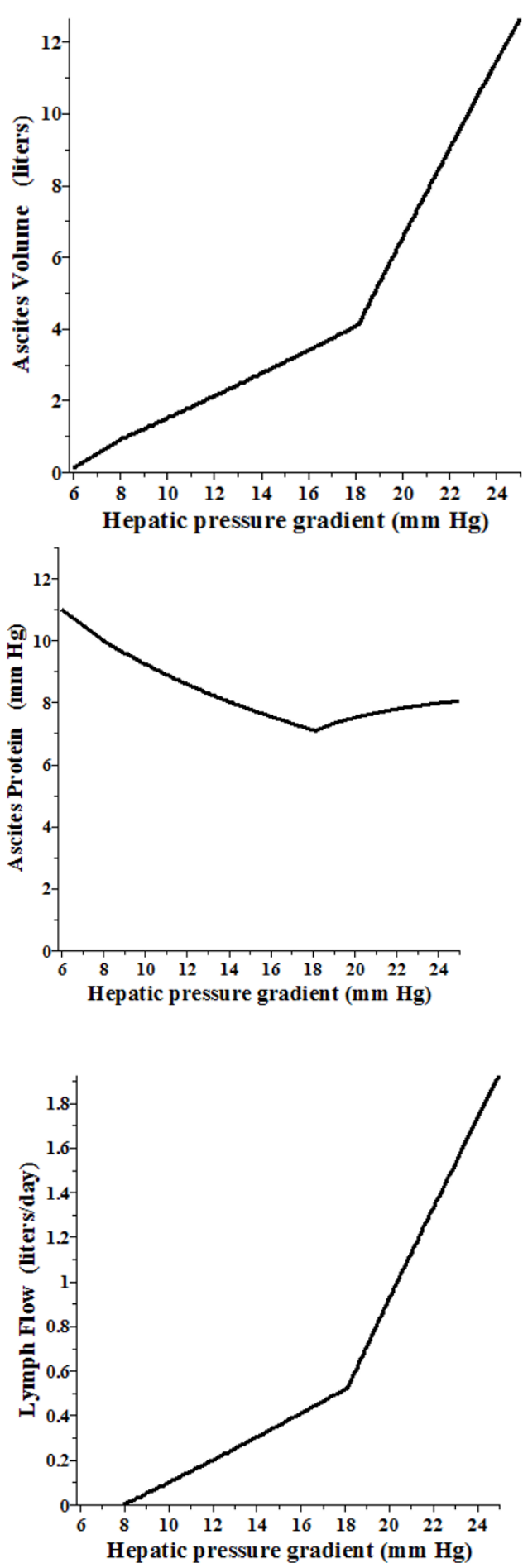

Figure 2 The model prediction for the steady state ascites volume (top), colloid osmotic pressure (middle) and lymph flow (bottom) as a function of the hepatic vein pressure gradient $\left(P_{\text {HVPG }}=\right.$ wedge - free $)$ the hepatic venous pressure gradient $\left(\mathrm{P}_{\mathrm{HVPG}}\right)$ and the right atrial pressure $\left(\mathrm{P}_{\mathrm{RA}}\right)$. Figure 3 shows how the steady state ascites volume in the original untreated condition (black line) is altered by either a) a $20 \%$ decrease in gradient (green line); b) a reduction in $\mathrm{P}_{\mathrm{RA}}$ from 5 to $2 \mathrm{~mm} \mathrm{Hg}$ (blue line), or c) a combination of both (a) and (b) (red line) as a function of the initial $\mathrm{P}_{\mathrm{HVPG}}$. For an initial gradient of $20 \mathrm{~mm} \mathrm{Hg}$, the ascites volume is reduced from about 6.5 to 1.0 liter if diuretics induced both of the above noted changes in $\mathrm{P}_{\mathrm{HVPG}}$ and $\mathrm{P}_{\mathrm{RA}}$. If the initial gradient is $16 \mathrm{~mm} \mathrm{Hg}$ or less, diuretics should produce complete reabsorption of the ascites. The reductions in $\mathrm{P}_{\mathrm{HVPG}}$ and $\mathrm{P}_{\mathrm{RA}}$ both contribute to the ascites reabsorption, but in different ways. At high initial $\mathrm{P}_{\mathrm{HVPG}}(>18 \mathrm{~mm} \mathrm{Hg}$ ), when the hepatic vein pressure becomes decoupled from $\mathrm{P}_{\mathrm{RA}}$ (eq. (13)), lowering $\mathrm{P}_{\mathrm{RA}}$ (Figure 3, blue line) has a relatively small effect, while lowering $\mathrm{P}_{\mathrm{HVPG}}$ (green line) has a larger effect. In contrast, in the low pressure regime when the hepatic vein pressure is equal to $\left(P_{R A}+2\right)$ (eq. (12)) lowering $P_{R A}$ (blue line) has a dramatic effect. For example, if the initial $\mathrm{P}_{\mathrm{HVPG}}$ is less than $13 \mathrm{~mm} \mathrm{Hg}$, lowering $\mathrm{P}_{\mathrm{RA}}$ from 5 to $2 \mathrm{~mm} \mathrm{Hg}$ is enough by itself to completely resolve the ascites. These predicted results indicate that the small changes in $\mathrm{P}_{\mathrm{HVPG}}$ and $\mathrm{P}_{\mathrm{RA}}$ clinically achievable with diuretics (see Table 1) can link the systemic

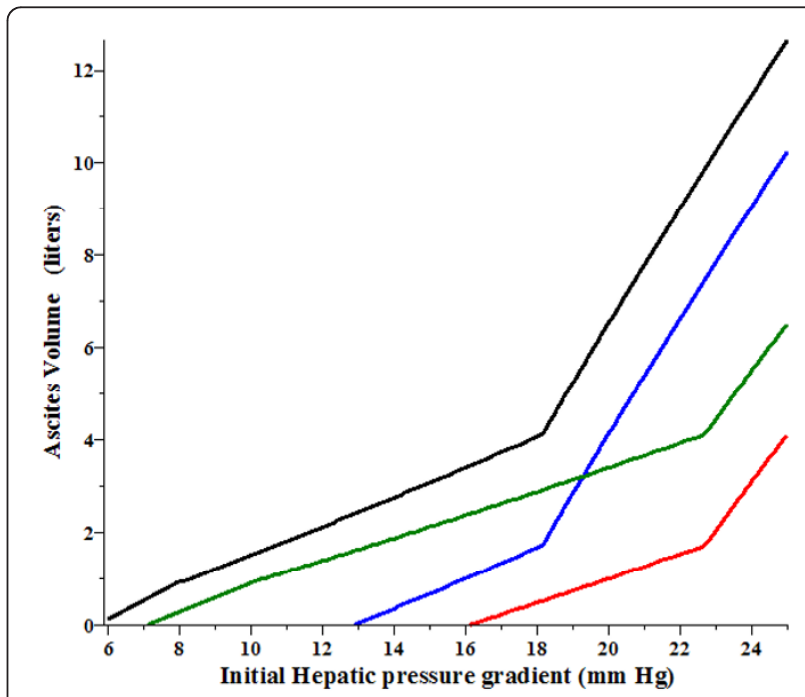

Figure 3 Decrease in the ascites volume from the untreated case (black line) produced by a) decrease in $\mathrm{P}_{\mathrm{HVPG}}$ by $20 \%$ (green), b) decrease of right atrial pressure $\left(P_{R A}\right)$ from 5 to 2 $\mathrm{mm} \mathrm{Hg}$ (blue) and c) decrease in both $\mathrm{P}_{\mathrm{HVPG}}$ by $20 \%$ decrease and $\mathrm{P}_{\mathrm{RA}}$ from 5 to $2 \mathrm{~mm} \mathrm{Hg}$ (red) as a function of the original $P_{\text {HVPG }}$ before treatment. 
changes induced by diuretics to fluid accumulation in the abdomen.

As discussed in Section IIF, propranolol produces a decrease in the $P_{H V P G}$ similar to that of the diuretics, but it also produces an increase in $\mathrm{P}_{\text {Free }}$ that results from an increase in $\mathrm{P}_{\mathrm{RA}}$. Figure 4 shows the predicted change in ascites volume (red line) produced by a $20 \%$ decrease in $P_{H V P G}$ and an increase in $P_{R A}$ from 5 to 7 $\mathrm{mm} \mathrm{Hg}$, similar to what is seen for propranolol (Table 1). It can be seen that for initial $P_{\text {HVPG }}$ less than about $18 \mathrm{~mm} \mathrm{Hg}$, propranolol would be predicted to produce an increase in ascites volume, despite the decrease in $P_{\text {HVPG. }}$.

A standard treatment for cirrhotic ascites is surgically produced portal systemic shunting [114]. Assuming that this procedure reduces portal flow with no change in liver resistance or central venous pressure, then the percent reduction in $\mathrm{P}_{\mathrm{HVPG}}$ is equal to the percent reduction in liver blood flow. Figure 5 shows the reduction in ascites volume produced by a $20 \%, 35 \%$ and $50 \%$ reduction in $\mathrm{P}_{\mathrm{HVPG}}$ or, equivalently, liver flow as a function of the initial $P_{\mathrm{HVPG}}$. It can be seen that in order to reduce ascites by shunting, large reductions (about $50 \%$ ) in flow are required. This is consistent with the results of Rogriguez-Laiz et. al. [115] that showed that transjugular intrahepatic portasystemic shunts (TIPS) reduced liver blood flow by about $50 \%$.

An important prediction of the model is that central venous pressure $\left(\mathrm{P}_{\mathrm{RA}}\right)$ plays a major role in ascites volume, independent of the $\mathrm{P}_{\text {HVPG }}$. For example, in a patient with an initial $\mathrm{P}_{\mathrm{HVPG}}$ of $16 \mathrm{~mm} \mathrm{Hg}$, a diuretic

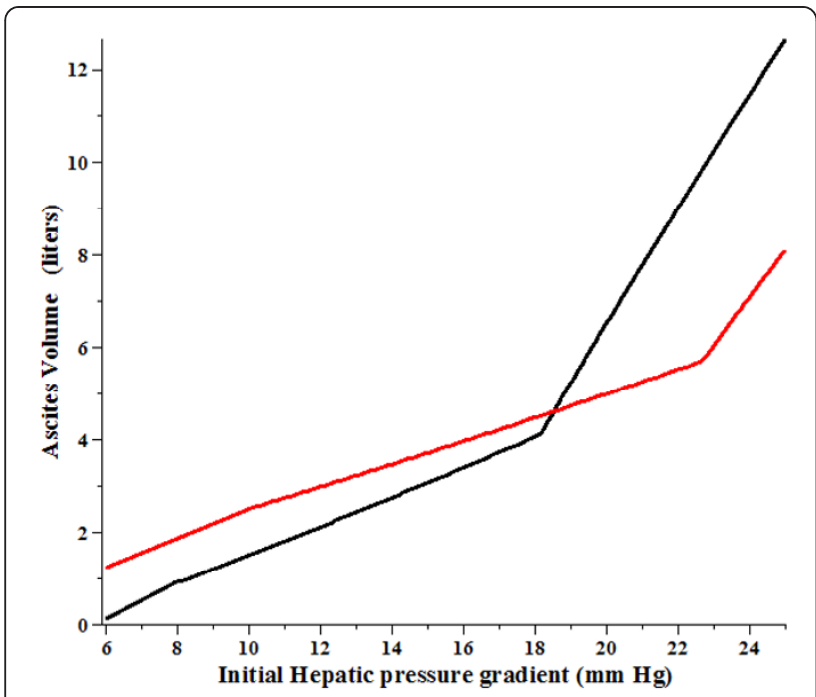

Figure 4 Change in the ascites volume from the untreated case (black line) produced by a decrease in $\mathrm{P}_{\mathrm{HVPG}}$ by $20 \%$ and an increase in $P_{R A}$ from 5 to $7 \mathrm{~mm} \mathrm{Hg}$ (red) as a function of the original $\mathrm{P}_{\mathrm{HVPG}}$ before treatment.

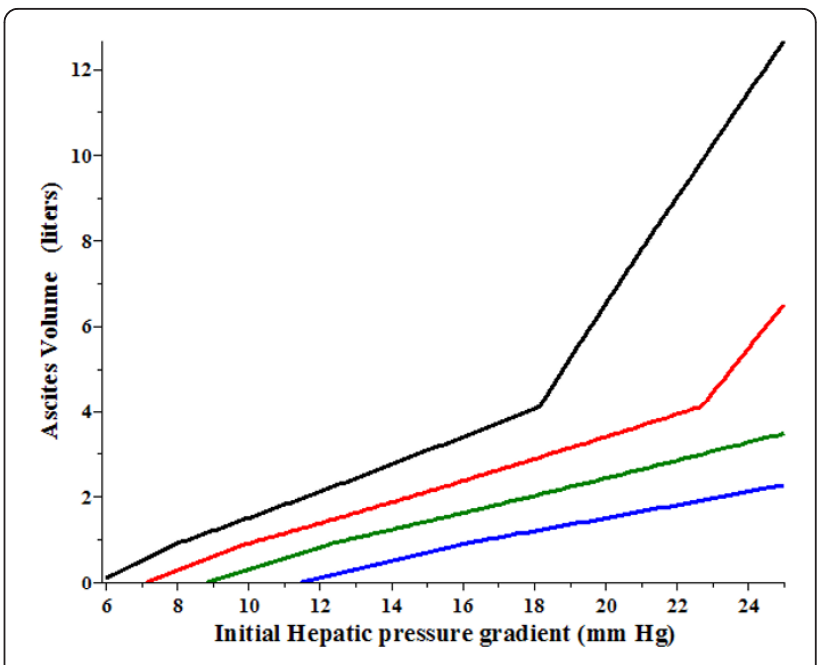

Figure 5 Change in the ascites volume from the untreated case (black line) produced by reduction of either $\mathrm{P}_{\text {HVPG }}$ or, equivalently, liver blood flow by $20 \%$ (red), $35 \%$ (green) or $50 \%$ (blue) as a function of the original $\mathrm{P}_{\mathrm{HVPG}}$ before treatment.

induced reduction in $\mathrm{P}_{\mathrm{RA}}$ of just $3 \mathrm{~mm} \mathrm{Hg}$ would reduce ascites volume from 3.5 liters to a clinically undetectable 0.8 liters, with no change in $\mathrm{P}_{\mathrm{HVPG}}$. Thus, the model is consistent with the clinical observation that that there may be only a loose correlation between the severity of ascites and $P_{\text {HVPG }}$. It should also be pointed out that there need be no relationship between the initial $P_{\text {HVPG }}$ of subjects and their responsiveness to diuretics. For example a patient with an initial $\mathrm{P}_{\mathrm{HVPG}}$ of $16 \mathrm{~mm} \mathrm{Hg}$ who cannot increase renal sodium output with diuretics (i.e., cannot reduce $\mathrm{P}_{\mathrm{RA}}$ or $\mathrm{P}_{\mathrm{HVPG}}$ in response to diuretics) will maintain an ascitic volume of about 3.5 liters. In contrast, a subject with an initial $\mathrm{P}_{\mathrm{HVPG}}$ of $20 \mathrm{mmHg}$ who is responsive to diuretics, such that the $\mathrm{P}_{\mathrm{RA}}$ falls by $3 \mathrm{mmHg}$ and the gradient by $4 \mathrm{mmHg}$, will have a reduction in ascitic volume from 6.5 liters to only 1 liter.

As discussed in Section IIF, it is expected that changes in plasma albumin should have a complicated effect on the severity of ascites. Figure 6 plots the predicted ascites volume as a function of $\mathrm{P}_{\mathrm{HVPG}}$ for plasma colloid osmotic pressure of $25 \mathrm{~mm} \mathrm{Hg}$ (black line), $20 \mathrm{~mm} \mathrm{Hg}$ (red), $15 \mathrm{~mm} \mathrm{Hg}$ (green) and $10 \mathrm{~mm} \mathrm{Hg}$ (blue). As expected (Section IIF), the increase in ascites volume produced by decreasing albumin is greatest at higher portal pressures and becomes negligible at $\mathrm{P}_{\mathrm{HVPG}}$ less than about $14 \mathrm{~mm} \mathrm{Hg}$. Even at $\mathrm{P}_{\mathrm{HVPG}}$ above14 $\mathrm{mm} \mathrm{Hg}$, the effect of decreasing oncotic pressure is relatively minor until this pressure reaches a value of $10 \mathrm{~mm} \mathrm{Hg}$ (equivalent to a serum albumin of about $1.5 \mathrm{gm} \%$ ). Thus, it is not surprising that many investigators have concluded that serum albumin infusion is not efficacious for the reduction of ascites. It also is apparent that no 


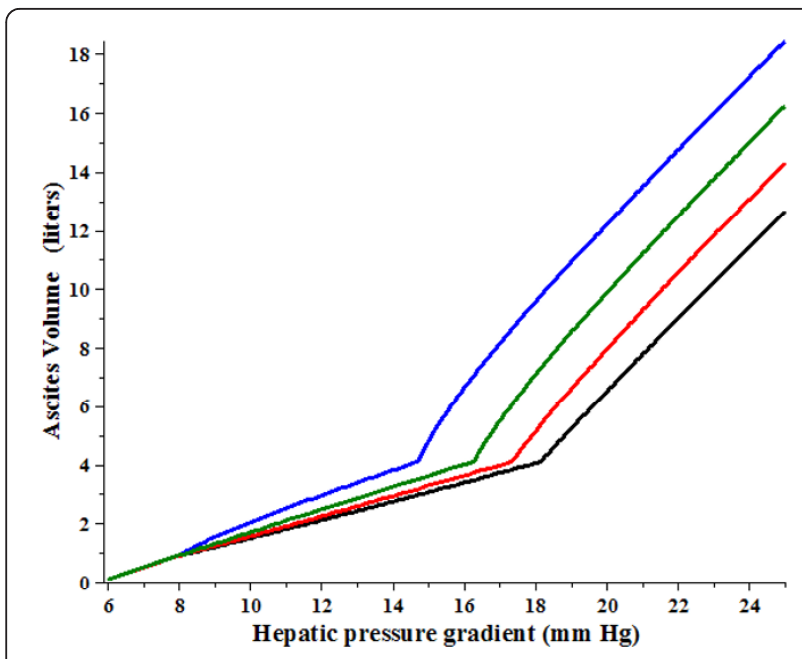

Figure 6 Ascites volume as a function of $\mathrm{P}_{\mathrm{HVPG}}$ for a plasma colloid osmotic pressure of $25 \mathrm{~mm} \mathrm{Hg}$ (black line), $20 \mathrm{~mm} \mathrm{Hg}$ (red), $15 \mathrm{~mm} \mathrm{Hg}$ (green), and $10 \mathrm{~mm} \mathrm{Hg}$ (blue).

ascites would be expected with very low serum albumin concentrations, providing the $\mathrm{P}_{\mathrm{HVPG}}$ is normal $(<6 \mathrm{~mm}$ $\mathrm{Hg}$ ). This prediction is borne out by the absence of ascites in subjects with congenital hypoalbumenemia $[116,117]$.

A time dependent model using the above relations and parameters was also developed. This is a detailed, general model which also includes the "intestinal" lymph flow and tissue compliance. The total "intestinal" hydraulic conductance $\left(\mathrm{L}_{\mathrm{T}}\right.$, eq. (18)) was divided equally between the intestinal capillaries and the intestinal mesothelium. (The following results do not depend significantly on this assumption). The solution requires the solution of 4 simultaneous differential equations. The details are described in the Additional file 1 Section II. Figure 7 shows the time dependent ascites volume change when, at time $=0$, the gradient $\left(\mathrm{P}_{\mathrm{HVPG}}\right)$ is suddenly raised to 20 $\mathrm{mm} \mathrm{Hg}$ and the right atrial pressure $\left(\mathrm{P}_{\mathrm{RA}}\right)$ is increased to $5 \mathrm{~mm} \mathrm{Hg}$. After 30 days, when the system has reached a steady state with a volume of 6.5 liters, the gradient is suddenly reduced by $20 \%$ (to $16 \mathrm{~mm} \mathrm{Hg}$ ) and $\mathrm{P}_{\mathrm{RA}}$ is reduced to $2 \mathrm{~mm} \mathrm{Hg}$. Over a period of about 5 days, the ascitic volume is reduced to about 1 liter. Figure 8 shows a similar plot, with the gradient raised to $16 \mathrm{~mm} \mathrm{Hg}$. A $20 \%$ reduction in gradient (and $\mathrm{P}_{\mathrm{RA}}$ reduced from 5 to 2 ) at 30 days leads to complete reabsorption of the ascites over a period of about 5 days. Figure 9 shows a plot of the volume change that might be expected following paracentesis. At $\mathrm{t}=0$ the gradient was raised to $20 \mathrm{~mm}$ $\mathrm{Hg}\left(\mathrm{P}_{\mathrm{RA}}=5\right)$ and the system reached a steady state at 30 days. Then, over a 12 hour period, 5.3 liters of ascitic fluid was removed following which the volume returned back to its initial volume over a period of about 5 days.

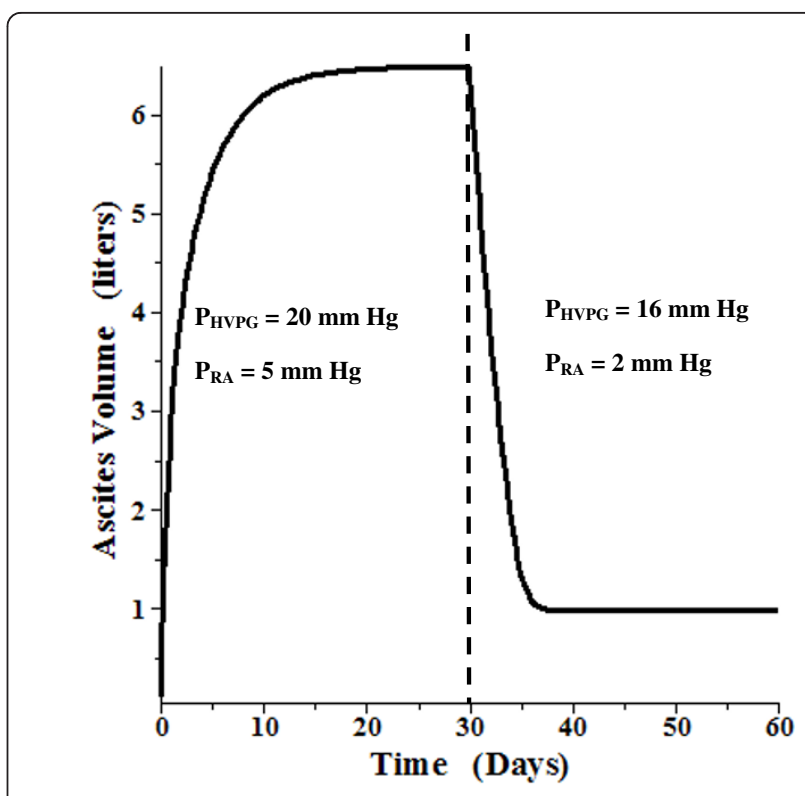

Figure 7 Time dependent change in ascites volume. At time 0 , the $P_{\text {HVPG }}$ is raised to $20 \mathrm{~mm} \mathrm{Hg}$ and $P_{\text {RA }}$ is raised to $5 \mathrm{~mm} \mathrm{Hg}$. After a steady state is reached at 30 days, $P_{\text {HVPG }}$ is reduced by $20 \%$ to $16 \mathrm{~mm} \mathrm{Hg}$ and $P_{\text {RA }}$ is lowered to $2 \mathrm{~mm} \mathrm{Hg}$.

The time dependence of these volume changes is similar to what is observed clinically [95].

We are unaware of any other attempts to quantitatively model ascites. The present model, which seemingly takes into account all factors involved in ascites accumulation, provides predictions that are in good accordance with

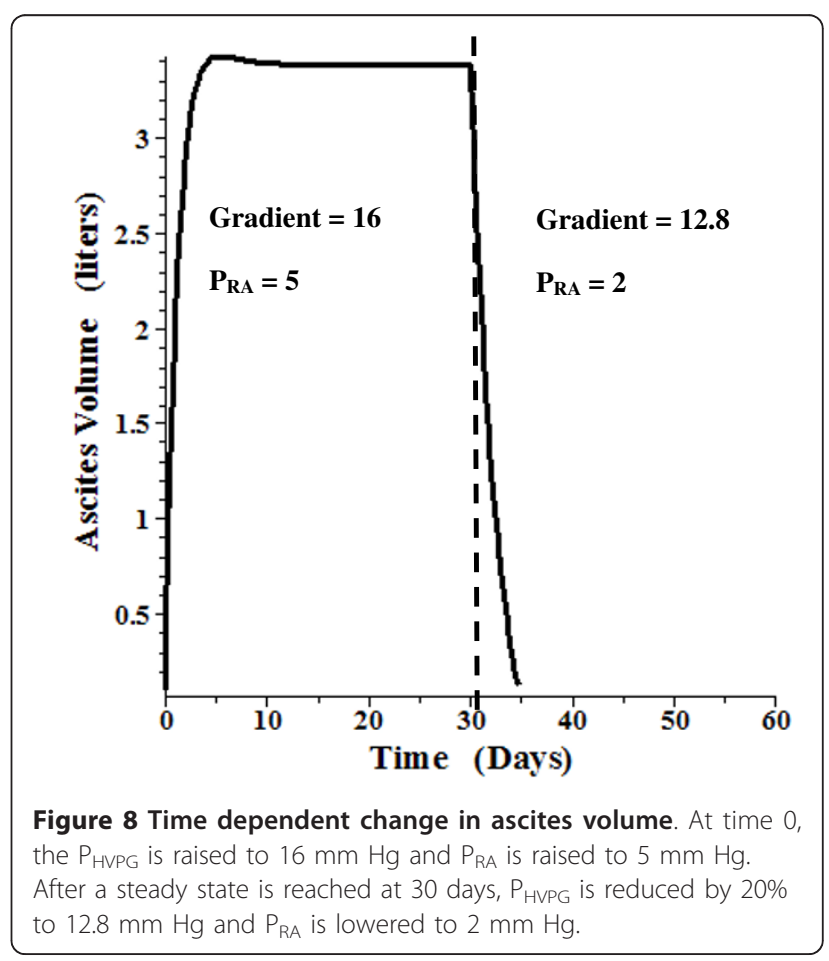




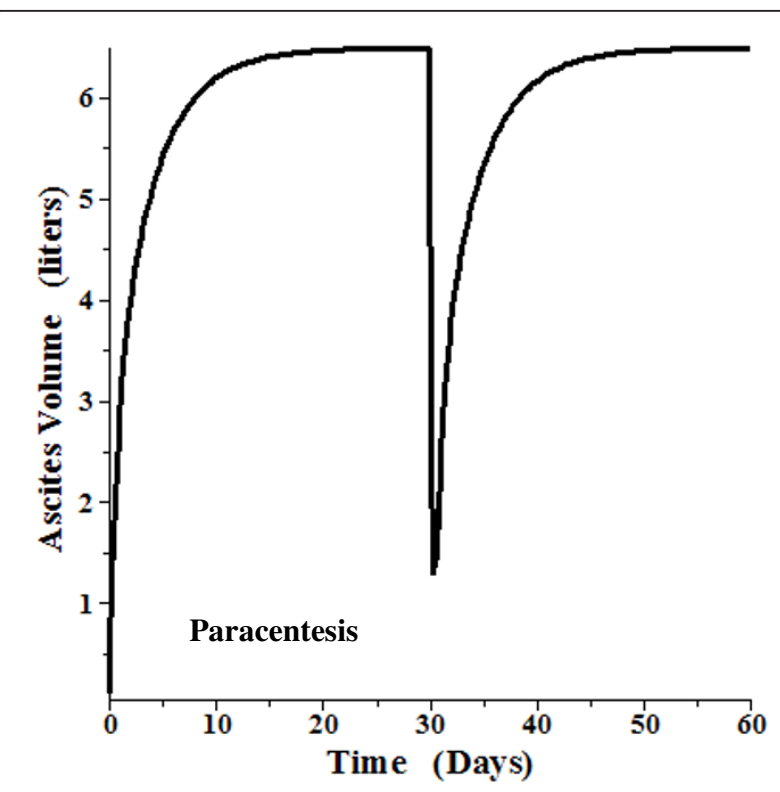

Figure 9 Time dependent change in ascites volume. At time 0 , the $P_{H V P G}$ is raised to $20 \mathrm{~mm} \mathrm{Hg}$ and $P_{R A}$ is raised to $5 \mathrm{~mm} \mathrm{Hg}$. After a steady state is reached at 30 days, 5.3 liters of ascites fluid is removed over a period of 12 hours and, over the next 10 days, the ascites reforms.

the major clinical observations in ascites. However, it should be emphasized that the model employs assumptions that have only indirect experimental support. Two major assumptions are the quantitative linear pressure dependence of both the fluid leak from the liver (eq. (19)) and the peritoneal lymph flow (eq. (20)). Although the leak should be a function of $\left(\mathrm{P}_{\mathrm{L}}-\mathrm{P}_{\mathrm{A}}\right)$, there is no evidence for the simple linear relation that is assumed. We are not aware of any measurements in humans that relate to the pressure dependence of the drainage of the peritoneal space. However, Zink and Greenway [94] showed in cats that the peritoneal fluid and protein absorption had an approximately linear dependence on pressure. Another important assumption in eq. (20) is that the lymph flow is sensitive to the central venous pressure $\left(\mathrm{P}_{\mathrm{RA}}\right)$. Although there are a number of observations that suggest that lymph flow is sensitive to thoracic duct pressure [28,118-121] and systemic venous pressure $[122,123]$, these results are indirect and not conclusive.

\section{Summary}

As discussed in the Introduction, in recent years ascites research largely has focused on the systemic changes observed in cirrhosis with particular emphasis on the "hyperdynamic circulation" syndrome. Although there is an implicit assumption that these changes cause ascites, there has been little discussion of the physiological link between these systemic alterations and ascites formation.
We theorize that ascites formation is dependent on just three factors: 1 ) the rate of protein leak from the liver, which is a function of the difference between the liver tissue pressure and the peritoneal pressure $\left(\mathrm{P}_{\mathrm{L}}\right.$ $\left.\mathrm{P}_{\mathrm{A}}\right)$; 2) the colloid osmotic fluid movement between the intestinal tissue and the peritoneal space; and 3) the rate of lymph drainage of the peritoneal space, which is a function of the peritoneal pressure $\left(\mathrm{P}_{\mathrm{A}}\right)$ and the central venous pressure $\left(\mathrm{P}_{\mathrm{RA}}\right)$. This theory is not entirely novel in that other investigators $[36,37,94,111]$ have recognized the role of these factors in ascites. Of particular importance is the work of Henriksen and colleagues that provides measurements of these factors in humans $[33,47,92,93,111]$.

In the standard "Forward theory" of ascites formation, there is a cycle of pathological events, ending with sodium and water retention and plasma volume expansion which then produce the ascites [6]. The mechanism involved in this last step is either not discussed or assumed to be an obvious result of the volume expansion. In terms of the model we have presented, this volume expansion must act through an increase in central venous pressure $\left(\mathrm{P}_{\mathrm{RA}}\right)$ and/or an increase in liver tissue pressure $\left(\mathrm{P}_{\mathrm{L}}\right)$ produced by an increase in liver blood flow (as a result of increasing cardiac output).

The novel aspect of the present report is the development of a quantitative model of ascites accumulation based solely on physiologically relevant estimations of $\left(\mathrm{P}_{\mathrm{L}}-\mathrm{P}_{\mathrm{A}}\right)$ and lymphatic drainage of the peritoneal cavity. The predictions of this model provide insight into a number of poorly understood clinical observations of the behavior of ascites in cirrhotic patients. For example, the model provides a quantitative explanation for the beneficial action of diuretics on ascites formation and the lack of efficacy of beta blockers despite their ability to reduce $\mathrm{P}_{\text {HVPG }}$. The model rather accurately predicts the known magnitude and time course of the action of diuretics on ascites. Lastly, the model provides a physiological explanation for the use of measurements of the SAAG to diagnose the existence of portal hypertension.

\section{Notation}

$\Pi_{\mathrm{P}}, \Pi_{\mathrm{A}}, \Pi_{\mathrm{L}}, \Pi_{\mathrm{I}}$, colloid osmotic pressure in plasma, peritoneal fluid, and interstitial fluid of liver and intestine.; $\mathrm{P}_{\mathrm{C}}, \mathrm{P}_{\mathrm{A}}, \mathrm{P}_{\mathrm{S}}, \mathrm{P}_{\mathrm{L}}, \mathrm{P}_{\mathrm{I}}, \mathrm{P}_{\mathrm{PV}}, \mathrm{P}_{\mathrm{HV}}, \mathrm{P}_{\mathrm{RA}}, \mathrm{P}_{\text {Wedge }}, \mathrm{P}_{\text {Free }}, \mathrm{P}_{\mathrm{HVPG}}$, hydrostatic pressure in intestinal capillary, peritoneal fluid, liver sinusoid, liver tissue, intestinal tissue, portal vein, hepatic vein, right atrium, the hepatic wedge and free pressures, and the hepatic vein pressure gradient (= wedge - free).; $J_{C}, J_{I}, J_{L}, J_{\text {lymph }}$, fluid flow rate across intestinal capillaries, intestinal mesothelium, liver capsule and peritoneal lymph flow.; $\mathrm{L}_{\mathrm{C}}, \mathrm{L}_{\mathrm{I}}, \mathrm{L}_{\mathrm{T}}$, hydraulic conductivity across intestinal capillary, intestinal mesothelium and total.; $\mathrm{F}_{\mathrm{L}}, \mathrm{R}_{\mathrm{L}}$, liver blood flow and 
resistance.; $\mathrm{L}_{\mathrm{y}}$, peritoneal lymph flow conductance.; $\mathrm{P}_{\min }$, zero lymph flow pressure.; $\mathrm{V}_{\min }$, peritoneal fluid volume when $\mathrm{P}_{\mathrm{A}}=\mathrm{P}_{\text {min }}$; $\mathrm{P}_{\text {Break }}$, pressure at which liver capsule and/or lymphatics rupture.; $\mathrm{m}$, protein concentration in fluid leaking from liver as fraction of plasma protein.

\section{Additional material}

Additional file 1: Experimental support for model and details of time dependent model solution.Experimental support for model and derivation of time dependent model solution.

\section{Author details}

'Department of Integrative Biology and Physiology, University of Minnesota, 6-125 Jackson Hall, 321 Church St. S. E., Minneapolis, MN 55455, USA.

${ }^{2}$ Research Service, Veterans Affairs Medical Center, VAMC/111D, 1 Veterans Drive, Minneapolis, MN 55417, USA.

\section{Authors' contributions}

$\mathrm{DGL}$ and $\mathrm{MDL}$ contributed equally to the manuscript. Both authors read and approved the final manuscript.

\section{Competing interests}

The authors declare that they have no competing interests.

Received: 15 December 2011 Accepted: 27 March 2012

Published: 27 March 2012

\section{References}

1. Starling EH: On the absorption of fluids from the connective tissue spaces. J Physio/ 1896, 19(4):312-326.

2. Rocco VK, Ware AJ: Cirrhotic ascites. Pathophysiology, diagnosis, and management. Ann Intern Med 1986, 105(4):573-585.

3. Dudley FJ: Pathophysiology of ascites formation. Gastroenterol Clin N Am 1992, 21(1):215-235.

4. In The Kidney in Liver Disease.. thirdth edition. Edited by: Epstein M. Baltimore: Williams 1988:

5. Wong $F$, Girgrah N, Blendis L: Review: the controversy over the pathophysiology of ascites formation in cirrhosis. $J$ Gastroenterol Hepatol 1997, 12(6):437-444.

6. Moller S, Henriksen JH, Bendtsen F: Ascites: pathogenesis and therapeutic principles. Scand J Gastroenterol 2009, 44(8):902-911.

7. Rosner MH, Gupta R, Ellison D, Okusa MD: Management of cirrhotic ascites: physiological basis of diuretic action. Eur J Intern Med 2006, 17(1):8-19.

8. La Villa G, Gentilini P: Hemodynamic alterations in liver cirrhosis. Mol Aspects Med 2008, 29(1-2):112-118.

9. Cardenas A, Bataller R, Arroyo V: Mechanisms of ascites formation. Clin Liver Dis 2000, 4(2):447-465.

10. Kashani A, Landaverde C, Medici V, Rossaro L: Fluid retention in cirrhosis: pathophysiology and management. QJM 2008, 101(2):71-85

11. Moore KP, Wong F, Gines $P$, Bernardi $M$, Ochs A, Salerno F, Angeli $P$, Porayko M, Moreau R, Garcia-Tsao G, et al: The management of ascites in cirrhosis: report on the consensus conference of the International Ascites Club. Hepatology 2003, 38(1):258-266.

12. Takasaki S, Hano H: Three-dimensional observations of the human hepatic artery (Arterial system in the liver). J Hepatol 2001, 34(3):455-466.

13. Witte $\mathrm{CL}$, Witte $\mathrm{MH}$, Dumont $\mathrm{AE}$, Frist J, Cole WR: Lymph protein in hepatic cirrhosis and experimental hepatic and portal venous hypertension. Ann Surg 1968, 168(4):567-577.

14. Cobb WS, Burns JM, Kercher KW, Matthews BD, James Norton H, Todd Heniford B: Normal intraabdominal pressure in healthy adults. J Surg Res 2005, 129(2):231-235.

15. Johnson PC, Richardson DR: The influence of venous pressure on filtration forces in the intestine. Microvasc Res 1974, 7(3):296-306.
16. Cogger VC, Le Couteur DG: Fenestrations in the liver sinusoidal endothelial cell. In The Liver: Biology and Pathobiology.. 5 edition. Edited by: Aria IM. Chichester: John Wiley 2009:

17. Laine GA, Hall JT, Laine SH, Granger J: Transsinusoidal fluid dynamics in canine liver during venous hypertension. Circ Res 1979, 45(3):317-323.

18. Barrowman JA, Granger DN: Effects of experimental cirrhosis on splanchnic microvascular fluid and solute exchange in the rat. Gastroenterology 1984, 87(1):165-172.

19. Abu-Hijleh MF, Habbal OA, Mogattash ST: The role of the diaphragm in lymphatic absorption from the peritoneal cavity. J Anat 1995, 186(Pt 3):453-467.

20. Mactier RA, Khanna R, Twardowski Z, Moore H, Nolph KD: Contribution of lymphatic absorption to loss of ultrafiltration and solute clearances in continuous ambulatory peritoneal dialysis. J Clin Invest 1987, 80(5):1311-1316

21. Schilling JA, Mc CA, Clausen SW, Troup SB, Mc KF: Experimental ascites; studies of electrolyte balance in dogs with partial and complete occlusion of the portal vein and of the vena cava above and below the liver. J Clin Invest 1952, 31(7):702-710.

22. Webster GJ, Burroughs AK, Riordan SM: Review article: portal vein thrombosis-new insights into aetiology and management. Aliment Pharmacol Ther 2005, 21(1):1-9.

23. Davis MJ, Gore RW: Capillary pressures in rat intestinal muscle and mucosal villi during venous pressure elevation. Am J Physiol 1985, 249(1 Pt 2):H174-H187.

24. Witte $\mathrm{CL}$, Myers JF, Witte MH, Katz MA: Transcapillary water and protein flux in the canine intestine with acute and chronic extrahepatic portal hypertension. Circ Res 1983, 53(5):622-629.

25. Bolton C, Barnard WG: The pathological occurences in the liver in experimental venous stagnation. J Pathol Bacteriol 1931, 34(6):701-709.

26. Greenway CV, Lautt WW: Effects of hepatic venous pressure on transsinusoidal fluid transfer in the liver of the anesthetized cat. Circ Res 1970, 26(6):697-703.

27. Hyatt RE, Lawrence GH, Smith JR: Observations on the origin of ascites from experimental hepatic congestion. J Lab Clin Med 1955, 45(2):274-280

28. Dumont $A E$, Mulholland JH: Alterations in thoracic duct lymph flow in hepatic cirrhosis: significance in portal hypertension. Ann Surg 1962, 156(4):668-675.

29. Kuntz E, Kuntz H: Hepatology textbook and atlas: history, morphology, biochemisty, diagnostics, clinic, therapy. 3 edition. Heidelberg: Springer; 2008.

30. Tameda Y, Yoshizawa N, Takase K, Nakano T, Kosaka Y: Prognostic value of peritoneoscopic findings in cirrhosis of the liver. Gastrointest Endosc 1990, 36(1):34-38.

31. Heit HA, Johnson LF, Rabin L: Liver surface characteristics as observed during laparoscopy correlated with biopsy findings. Gastrointest Endosc 1978, 24(6):288-290.

32. Braet F, Wisse E: Structural and functional aspects of liver sinusoidal endothelial cell fenestrae: a review. Comp Hepatol 2002, 1(1):1

33. Henriksen $\mathrm{JH}$, Horn T, Christoffersen P: The blood-lymph barrier in the liver. A review based on morphological and functional concepts of normal and cirrhotic liver. Liver 1984, 4(4):221-232

34. Dudley FJ: Management of refractory ascites. J Gastroenterol Hepatol 2004 19:S194-S199.

35. Khalid SK, Garcia-Tsao G: Ascites. Clinical features, diagnosis and natural history. In Portal Hypertension. Edited by: Sanyal AJ, Shah VH. Totowa: Humana Press, Inc; 2005:285-299.

36. Guyton AC: Textbook of medical Physiology. 6 edition. W. B. Saunders: Philadelphia; 1981

37. Witte $\mathrm{MH}$, Witte $\mathrm{CL}$, Dumont $\mathrm{AE}$ : Progress in liver disease: physiological factors involved in the causation of cirrhotic ascites. Gastroenterology $1971,61(5): 742-750$

38. Shibayama Y, Nakata K: Localization of increased hepatic vascular resistance in liver cirrhosis. Hepatology 1985, 5(4):643-648.

39. Lautt WW, Greenway CV, Legare DJ, Weisman H: Localization of intrahepatic portal vascular resistance. Am J Physiol 1986, 251(3 Pt 1): G375-G381.

40. Laleman W, Landeghem L, Wilmer A, Fevery J, Nevens F: Portal hypertension: from pathophysiology to clinical practice. Liver Int 2005 , 25(6):1079-1090

41. Maass-Moreno R, Rothe CF: Nonlinear resistances in hepatic microcirculation. Am J Physiol 1995, 269(6 Pt 2):H1922-H1930. 
42. Reynaert H, Urbain D, Geerts A: Regulation of sinusoidal perfusion in portal hypertension. Anat Rec (Hoboken) 2008, 291(6):693-698.

43. Boyer TD, Triger DR, Horisawa M, Redeker AG, Reynolds TB: Direct transhepatic measurement of portal vein pressure using a thin needle. Comparison with wedged hepatic vein pressure. Gastroenterology 1977, 72(4 Pt 1):584-589.

44. Perello A, Escorsell A, Bru C, Gilabert R, Moitinho E, Garcia-Pagan JC, Bosch J: Wedged hepatic venous pressure adequately reflects portal pressure in hepatitis C virus-related cirrhosis. Hepatology 1999, 30(6):1393-1397.

45. Pomier-Layrargues G, Kusielewicz D, Willems B, Villeneuve JP, Marleau D, Cote J, Huet PM: Presinusoidal portal hypertension in non-alcoholic cirrhosis. Hepatology 1985, 5(3):415-418.

46. Thalheimer U, Leandro G, Samonakis DN, Triantos CK, Patch D, Burroughs AK: Assessment of the agreement between wedge hepatic vein pressure and portal vein pressure in cirrhotic patients. Dig Liver Dis 2005, 37(8):601-608.

47. Henriksen JH, Stage JG, Schlichting P, Winkler K: Intraperitoneal pressure: ascitic fluid and splanchnic vascular pressures, and their role in prevention and formation of ascites. Scand J Clin Lab Invest 1980, 40(6):493-501.

48. La Mura V, Abraldes JG, Berzigotti A, Erice E, Flores-Arroyo A, GarciaPagan JC, Bosch J: Right atrial pressure is not adequate to calculate portal pressure gradient in cirrhosis: a clinical-hemodynamic correlation study. Hepatology 2010, 51(6):2108-2116.

49. Moller S, Hobolth L, Winkler C, Bendtsen F, Christensen E: Determinants of the hyperdynamic circulation and central hypovolaemia in cirrhosis. Gut 2011, 60(9):1254-1259.

50. Gore RW, Bohlen HG: Microvascular pressures in rat intestinal muscle and mucosal villi. Am J Physiol 1977, 233(6):H685-H693.

51. Garcia-Pagan JC, Salmeron JM, Feu F, Luca A, Gines P, Pizcueta P, Claria J, Piera C, Arroyo V, Bosch J, et al: Effects of low-sodium diet and spironolactone on portal pressure in patients with compensated cirrhosis. Hepatology 1994, 19(5):1095-1099.

52. Sen S, De BK, Biswas PK, Biswas J, Das D, Maity AK: Hemodynamic effect of spironolactone in liver cirrhosis and propranolol-resistant portal hypertension. Indian J Gastroenterol 2002, 21(4):145-148.

53. Katsuta Y, Aramaki T, Sekiyama T, Satomura K, Okumura H, Okumura K: Plasma volume contraction in portal hypertension. J Hepatol 1993, 17(Suppl 2):S19-S23.

54. Sugano S, Kawafune T, Okajima T, Ishii K, Watanabe M, Takamura N: Chronic splanchnic hemodynamic effects of spironolactone with unrestricted sodium diet in patients with compensated cirrhosis. Dig Dis Sci 1998, 43(4):893-897.

55. Cereda JM, Roulot D, Braillon A, Moreau R, Koshy A, Lebrec D: Reduction of portal pressure by acute administration of furosemide in patients with alcoholic cirrhosis. J Hepatol 1989, 9(2):246-251.

56. Bosch J, Masti R, Kravetz D, Bruix J, Gaya J, Rigau J, Rodes J: Effects of propranolol on azygos venous blood flow and hepatic and systemic hemodynamics in cirrhosis. Hepatology 1984, 4(6):1200-1205.

57. Pomier-Layrargues G, Villeneuve JP, Willems B, Huet PM, Marleau D: Systemic and hepatic hemodynamics after variceal hemorrhage: effects of propranolol and placebo. Gastroenterology 1987, 93(6):1218-1224.

58. Aramaki $T$, Sekiyama $T$, Katsuta $Y$, Kurokawa $H$, Komeichi $H$, Tsutsui $H$, Terada H, Ohsuga M, Satomura K, Okumura H: Long-term haemodynamic effects of a 4-week regimen of nipradilol, a new beta-blocker with nitrovasodilating properties, in patients with portal hypertension due to cirrhosis. A comparative study with propranolol. J Hepatol 1992, 15(12):48-53.

59. Braillon A, Cales P, Valla D, Gaudy D, Geoffroy P, Lebrec D: Influence of the degree of liver failure on systemic and splanchnic haemodynamics and on response to propranolol in patients with cirrhosis. Gut 1986 27(10):1204-1209.

60. Banares R, Moitinho E, Matilla A, Garcia-Pagan JC, Lampreave JL, Piera C, Abraldes JG, De Diego A, Albillos A, Bosch J: Randomized comparison of long-term carvedilol and propranolol administration in the treatment of portal hypertension in cirrhosis. Hepatology 2002, 36(6):1367-1373.

61. Baik SK, Park DH, Kim MY, Choi YJ, Kim HS, Lee DK, Kwon SO, Kim YJ, Park JW, Chang SJ: Captopril reduces portal pressure effectively in portal hypertensive patients with low portal venous velocity. J Gastroenterol 2003, 38(12):1150-1154.
62. De BK, Bandyopadhyay K, Das TK, Das D, Biswas PK, Majumdar D, Mandal SK, Ray S, Dasgupta S: Portal pressure response to losartan compared with propranolol in patients with cirrhosis. Am J Gastroenterol 2003, 98(6):1371-1376.

63. Escorsell A, Ferayorni L, Bosch J, Garcia-Pagan JC, Garcia-Tsao G, Grace ND, Rodes J, Groszmann RJ: The portal pressure response to beta-blockade is greater in cirrhotic patients without varices than in those with varices. Gastroenterology 1997, 112(6):2012-2016.

64. Roulot D, Moreau R, Gaudin C, Bacq Y, Braillon A, Hadengue A, Frohly P, Lebrec $D$ : Long-term sympathetic and hemodynamic responses to clonidine in patients with cirrhosis and ascites. Gastroenterology 1992, 102(4 Pt 1):1309-1318.

65. Moreau R, Lee SS, Hadengue A, Braillon A, Lebrec D: Hemodynamic effects of a clonidine-induced decrease in sympathetic tone in patients with cirrhosis. Hepatology 1987, 7(1):149-154.

66. Albillos A, Banares R, Barrios C, Clemente G, Rossi I, Escartin P, Bosch J: Oral administration of clonidine in patients with alcoholic cirrhosis. Hemodynamic and liver function effects. Gastroenterology 1992, 102(1):248-254.

67. Garcia-Tsao G, Groszmann RJ: Portal hemodynamics during nitroglycerin administration in cirrhotic patients. Hepatology 1987, 7(5):805-809.

68. Iwao T, Toyonaga A, Sumino M, Takagi K, Ohkubo K, Inoue R, Tanikawa K: Hemodynamic study during transdermal application of nitroglycerin tape in patients with cirrhosis. Hepatology 1991, 13(1):124-128.

69. Moreau R, Roulot D, Braillon A, Gaudin C, Hadengue A, Bacq Y, Lebrec D: Low dose of nitroglycerin failed to improve splanchnic hemodynamics in patients with cirrhosis: evidence for an impaired cardiopulmonary baroreflex function. Hepatology 1989, 10(1):93-97.

70. Bosch J, Bordas JM, Mastai R, Kravetz D, Navasa M, Chesta J, Pizcueta MP, Garcia-Pagan JC, Rodes J: Effects of vasopressin on the intravariceal pressure in patients with cirrhosis: comparison with the effects on portal pressure. Hepatology 1988, 8(4):861-865.

71. Groszmann RJ, Kravetz D, Bosch J, Glickman M, Bruix J, Bredfeldt J, Conn HO, Rodes J, Storer EH: Nitroglycerin improves the hemodynamic response to vasopressin in portal hypertension. Hepatology 1982, 2(6):757-762.

72. Bosch J, Kravetz D, Rodes J: Effects of somatostatin on hepatic and systemic hemodynamics in patients with cirrhosis of the liver: comparison with vasopressin. Gastroenterology 1981, 80(3):518-525.

73. Romero G, Kravetz D, Argonz J, Bildozola M, Suarez A, Terg R: Terlipressin is more effective in decreasing variceal pressure than portal pressure in cirrhotic patients. J Hepatol 2000, 32(3):419-425

74. Ibarra FR, Afione C, Garzon D, Barontini M, Santos JC, Arrizurieta E: Portal pressure, renal function and hormonal profile after acute and chronic captopril treatment in cirrhosis. Eur J Clin Pharmacol 1992, 43(5):477-482.

75. Chiang HT, Cheng JS, Lin M, Tseng WS, Chang JM, Lai KH: Haemodynamic effects of enalaprilat on portal hypertension in patients with $\mathrm{HBsAg}$ positive cirrhosis. J Gastroenterol Hepatol 1995, 10(3):256-260.

76. Tripathi D, Therapondos G, Lui HF, Johnston N, Webb DJ, Hayes PC: Chronic administration of losartan, an angiotensin II receptor antagonist, is not effective in reducing portal pressure in patients with preascitic cirrhosis. Am J Gastroenterol 2004, 99(2):390-394.

77. Arroyo V, Bosch J, Mauri M, Ribera F, Navarro-Lopez F, Rodes J: Effect of angiotensin-II blockade on systemic and hepatic haemodynamics and on the renin-angiotensin-aldosterone system in cirrhosis with ascites. Eur J Clin Investig 1981, 11(3):221-229.

78. Vlavianos P, Polson RJ, Settin A, Glover J, Westaby D, Williams R: Haemodynamic and pharmacokinetic study of intravenous fenoldopam in patients with hepatic cirrhosis. Br J Clin Pharmacol 1990, 29(1):19-25.

79. Luca A, Feu F, Garcia-Pagan JC, Jimenez W, Arroyo V, Bosch J, Rodes J: Favorable effects of total paracentesis on splanchnic hemodynamics in cirrhotic patients with tense ascites. Hepatology 1994, 20(1 Pt 1):30-33.

80. Krook H: Estimation of portal venous pressure by occlusive hepatic vein catheterization. Scand J Clin Lab Invest 1953, 5(3):285-292.

81. Myers JD, Taylor WJ: Occlusive hepatic venous catheterization in the study of the normal liver, cirrhosis of the liver and noncirrhotic portal hypertension. Circulation 1956, 13(3):368-380.

82. Paton A, Reynolds TB, Sherlock S: Assessment of portal venous hypertension by catheterisation of hepatic vein. Lancet 1953, 1(6767):918-921. 
83. Malbrain ML: Different techniques to measure intra-abdominal pressure (IAP): time for a critical re-appraisal. Intensive Care Med 2004, 30(3):357-371.

84. Rector WG Jr: Portal hypertension: a permissive factor only in the development of ascites and variceal bleeding. Liver 1986, 6(4):221-226

85. Morali GA, Sniderman KW, Deitel KM, Tobe S, Witt-Sullivan H, Simon M, Heathcote J, Blendis LM: Is sinusoidal portal hypertension a necessary factor for the development of hepatic ascites? J Hepatol 1992, 16(12):249-250.

86. Meng HC, Lin HC, Tsai YT, Lee FY, Liao DM, Hsia HC, Lin WJ, Chang TT, Lay CS, Wang SS, et al: Relationships between the severity of cirrhosis and haemodynamic values in patients with cirrhosis. $J$ Gastroenterol Hepatol 1994, 9(2):148-153.

87. Casado M, Bosch J, Garcia-Pagan JC, Bru C, Banares R, Bandi JC, Escorsell A, Rodriguez-Laiz JM, Gilabert R, Feu F, et al: Clinical events after transjugular intrahepatic portosystemic shunt: correlation with hemodynamic findings. Gastroenterology 1998, 114(6):1296-1303.

88. Flessner M: Effective lymphatic absorption rate is not a useful or accurate term to use in the physiology of peritoneal dialysis. Perit Dial Int 2004, 24(4):313-316, discussion 316-317.

89. Krediet RT: The effective lymphatic absorption rate is an accurate and useful concept in the physiology of peritoneal dialysis. Perit Dial Int 2004, 24(4):309-313, discussion 316-307.

90. Rippe B, Stelin G, Ahlmen J: Lymph flow from the peritoneal cavity in CAPD patients. In International symposium on peritoneal dialysis, 3 rd: 1986 1984; Washington D. C. Edited by: Maher JF, Winchester JF. Field, Rich and Associates; 1984:24-30.

91. Simonsen O, Venturoli D, Wieslander A, Carlsson O, Rippe B: Mass transfer of calcium across the peritoneum at three different peritoneal dialysis fluid Ca2+ and glucose concentrations. Kidney Int 2003, 64(1):208-215.

92. Henriksen $J H$, Lassen NA, Parving HH, Winkler K: Filtration as the main transport mechanism of protein exchange between plasma and the peritoneal cavity in hepatic cirrhosis. Scand I Clin Lab Invest 1980, 40(6):503-513.

93. Henriksen JH, Siemssen O, Krintel JJ, Malchow-Moller A, Bendtsen F, RingLarsen $\mathrm{H}$ : Dynamics of albumin in plasma and ascitic fluid in patients with cirrhosis. J Hepatol 2001, 34(1):53-60.

94. Zink J, Greenway CV: Control of ascites absorption in anesthetized cats: effects of intraperitoneal pressure, protein, and furosemide diuresis. Gastroenterology 1977, 73(5):1119-1124.

95. Shear L, Ching S, Gabuzda GJ: Compartmentalization of ascites and edema in patients with hepatic cirrhosis. N Engl J Med 1970, 282(25):1391-1396

96. Runyon BA, Montano AA, Akriviadis EA, Antillon MR, Irving MA, McHutchison JG: The serum-ascites albumin gradient is superior to the exudate-transudate concept in the differential diagnosis of ascites. Ann Intern Med 1992, 117(3):215-220.

97. Myers RP, Cerini R, Sayegh R, Moreau R, Degott C, Lebrec D, Lee SS: Cardiac hepatopathy: clinical, hemodynamic, and histologic characteristics and correlations. Hepatology 2003, 37(2):393-400.

98. Rector WG Jr, Reynolds TB: Propranolol in the treatment of cirrhotic ascites. Arch Intern Med 1984, 144(9):1761-1763.

99. Groszmann RJ, Garcia-Tsao G, Bosch J, Grace ND, Burroughs AK, Planas R, Escorsell A, Garcia-Pagan JC, Patch D, Matloff DS, et al: Beta-blockers to prevent gastroesophageal varices in patients with cirrhosis. N Engl J Med 2005, 353(21):2254-2261.

100. Lenaerts A, Codden T, Meunier JC, Henry JP, Ligny G: Effects of clonidine on diuretic response in ascitic patients with cirrhosis and activation of sympathetic nervous system. Hepatology 2006, 44(4):844-849.

101. Garcia-Tsao G, Bosch J: Management of varices and variceal hemorrhage in cirrhosis. N Engl J Med 2010, 362(9):823-832.

102. Tincani E, Cioni G, D'Alimonte P, Cristani A, Turrini F, Romagnoli R, Ventura E: Effects of propranolol compared with clonidine on portal haemodynamics: a double-blind cross-over study using duplex-Doppler ultrasonography. Eur J Gastroenterol Hepatol 1995, 7(9):893-897.

103. Tandon P, Abraldes JG, Berzigotti A, Garcia-Pagan JC, Bosch J: Reninangiotensin-aldosterone inhibitors in the reduction of portal pressure: a systematic review and meta-analysis. J Hepatol 2010, 53(2):273-282.

104. Vlachogiannakos J, Tang AK, Patch D, Burroughs AK: Angiotensin converting enzyme inhibitors and angiotensin II antagonists as therapy in chronic liver disease. Gut 2001, 49(2):303-308.
105. Wong F, Watson H, Gerbes A, Vilstrup H, Badalamenti S, Bernardi M, Gines P: Satavaptan for the management of ascites in cirrhosis: efficacy and safety across the spectrum of ascites severity. Gut 2012, 61(1):108-116.

106. Trotter J, Pieramici E, Everson GT: Chronic albumin infusions to achieve diuresis in patients with ascites who are not candidates for transjugular intrahepatic portosystemic shunt (TIPS). Dig Dis Sci 2005, 50(7):1356-1360.

107. Gentilini P, Casini-Raggi V, Di Fiore G, Romanelli RG, Buzzelli G, Pinzani M, La Villa G, Laffi G: Albumin improves the response to diuretics in patients with cirrhosis and ascites: results of a randomized, controlled trial. J Hepatol 1999, 30(4):639-645.

108. Jahn H, Schon D: Cariovascular effects of loop diuretics. In Diuretics II: Chemistry, parmacology, and clinical applications: 1986; Cascais, Portugal. Edited by: Puschett J, Greenberg A. Elsevier; 1986:325-331.

109. Schohn DC, Jahn HA, Pelletier BC: Dose-related cardiovascular effects of spironolactone. Am J Cardiol 1993, 71(3):40A-45A.

110. Rippe B, Levin L: Computer simulations of ultrafiltration profiles for an icodextrin-based peritoneal fluid in CAPD. Kidney Int 2000, 57(6):2546-2556.

111. Henriksen JH, Parving HH, Christiansen LA, Lassen NA, Ring-Larsen $H$, Winkler K: The effect of ascitic fluid hydrostatic pressure on albumin extravasation rate in patients with cirrhosis of the liver. Scand I Clin Lab Invest 1981, 41(6):601-609.

112. Lieberman FL, Ito S, Reynolds TB: Effective plasma volume in cirrhosis with ascites. Evidence that a decreased value does not account for renal sodium retention, a sponteneous reduction in glomerular filtration rate (GFR), and a fall in GFR during drug-induced diuresis. J Clin Invest 1969, 48(6):975-981.

113. Nitta S, Ohnuki T, Ohkuda K, Nakada T, Staub NC: The corrected protein equation to estimate plasma colloid osmotic pressure and its development on a nomogram. Tohoku J Exp Med 1981, 135(1):43-49.

114. Gines P, Uriz J, Calahorra B, Garcia-Tsao G, Kamath PS, Del Arbol LR, Planas R, Bosch J, Arroyo V, Rodes J: Transjugular intrahepatic portosystemic shunting versus paracentesis plus albumin for refractory ascites in cirrhosis. Gastroenterology 2002, 123(6):1839-1847.

115. Rodriguez-Laiz JM, Banares R, Echenagusia A, Casado M, Camunez F, PerezRoldan F, de Diego A, Cos E, Clemente G: Effects of transjugular intrahepatic portasystemic shunt (TIPS) on splanchnic and systemic hemodynamics, and hepatic function in patients with portal hypertension. Preliminary results. Dig Dis Sci 1995, 40(10):2121-2127.

116. Campagnoli M, Hansson P, Dolcini L, Caridi G, Dagnino M, Candiano G, Bruschi M, Palmqvist L, Galliano M, Minchiotti L: Analbuminemia in a Swedish male is caused by the Kayseri mutation (c228_229delAT). Clinica Chimica Acta 2008, 396(1-2):89-92.

117. Russi E, Weigand K: Analbuminemia. Klin Wochenschr 1983, 61(11):541-545.

118. Dumont AE: Thoracic-duct-to-esophagus shunt. Transplantation 1987, 43(2):320.

119. Dumont AE, Mulholland JH: Flow rate and composition of thoracic-duct lymph in patients with cirrhosis. N Engl J Med 1960, 263:471-474.

120. Zotti EF: Prevention and treatment of experimental ascites due to stenosis of the inferior vena cava in dogs. (A new technic of anastomosis between the thoracic duct and the venous system). Acta Chir Ital 1966, 22(6):679-692.

121. Dumont AE, Clauss RH, Reed GE, Tice DA: Lymph Drainage in Patients with Congestive Heart Failure. Comparison with Findings in Hepatic Cirrhosis. N Engl J Med 1963, 269:949-952.

122. Szabo G, Magyar Z: Effect of increased systemic venous pressure on lymph pressure and flow. Am J Physiol 1967, 212(6):1469-1474.

123. Sakai T, Yabuki S, Chang K, Kambayashi T, Nakamura R, Takeyasu N, Taira K, Hirota A, Machii K, Seki K: Effect of increased systemic venous pressure on thoracic duct and peripheral lymph flow in dogs. Lymphology 1985, 18(2):64-67.

\section{Pre-publication history}

The pre-publication history for this paper can be accessed here: http://www.biomedcentral.com/1471-230X/12/26/prepub

doi:10.1186/1471-230X-12-26

Cite this article as: Levitt and Levitt: Quantitative modeling of the physiology of ascites in portal hypertension. BMC Gastroenterology 2012 12:26. 